\title{
Recognition of district-wise groundwater stress zones using the GLDAS-2 catchment land surface model during lean season in the Indian state of West Bengal
}

\author{
Satiprasad Sahoo ${ }^{1}$. Subha Chakraborty ${ }^{2}$ Q Quoc Bao Pham ${ }^{3,4}$. Ehsan Sharifi ${ }^{5}$ Saad Sh. Sammen ${ }^{6}$. Matej Vojtek ${ }^{7}$. \\ Jana Vojteková ${ }^{7} \cdot$ Ismail Elkhrachy ${ }^{8,9} \cdot$ Romulus Costache $^{10,11} \cdot$ Nguyen Thi Thuy Linh $^{12,13}$
}

Received: 18 June 2020 / Accepted: 4 November 2020 / Published online: 2 January 2021

(C) Institute of Geophysics, Polish Academy of Sciences \& Polish Academy of Sciences 2021

\begin{abstract}
Water is essential for irrigation, drinking and industrial purposes from global to the regional scale. The groundwater considered a significant water resource specifically in regions where the surface water is not sufficient. Therefore, the research problem is focused on district-wise sustainable groundwater management due to urbanization. The number of impervious surface areas like roofing on built-up areas, concrete and asphalt road surface were increased due to the level of urban development. Thus, these surface areas can inhibit infiltration and surface retention by the impact of urbanization because vegetation/forest areas are decreased. The present research examines the district-wise spatiotemporal groundwater storage (GWS) changes under terrestrial water storage using the global land data assimilation system-2 (GLDAS-2) catchment land surface model (CLSM) from 2000 to 2014 in West Bengal, India. The objective of the research is mainly focused on the delineation of groundwater stress zones (GWSZs) based on ten biophysical and hydrological factors according to the deficiency of groundwater storage using the analytic hierarchy process by the GIS platform. Additionally, the spatiotemporal soil moisture (surface soil moisture, root zone soil moisture, and profile soil moisture) changes for the identification of water stress areas using CLSM were studied. Finally, generated results were validated by the observed groundwater level and groundwater recharge data. The sensitivity analysis has been performed for GWSZs mapping due to the deficit of groundwater storage. Three correlation coefficient methods (Kendall, Pearson and Spearman) are applied for the interrelationship between the most significant parameters for the generation of GWSZ from sensitivity analysis. The results show that the northeastern (max: $1097.35 \mathrm{~mm}$ ) and the southern (max: $993.22 \mathrm{~mm}$ ) parts have high groundwater storage due to higher amount of soil moisture and forest cover compared to other parts of the state. The results also show that the maximum and minimum total annual groundwater recharge shown in Paschim Medinipore [(361,148.51 hectare-meter (ham)] and Howrah (31,510.46 ham) from 2012 to 2013. The generated outcome can create the best sustainable groundwater management practices based upon the human attitude toward risk.
\end{abstract}

Keywords Soil moisture $\cdot$ Terrestrial water storage $\cdot$ Groundwater storage $\cdot$ Catchment land surface model $\cdot$ Groundwater stress · GIS

Communicated by Michael Nones, Ph.D. (CO-EDITOR-INCHIEF)/Mohammad Valipour (ASSOCIATE EDITOR).

Electronic supplementary material The online version of this article (https://doi.org/10.1007/s11600-020-00509-x) contains supplementary material, which is available to authorized users.

Nguyen Thi Thuy Linh

nguyentthuylinh58@duytan.edu.vn

Extended author information available on the last page of the article

\section{Introduction}

Groundwater plays a vital role in agriculture, domestic and industrial sectors for the development of the arid and semiarid zones because of the unavailability or insufficiently of surface water. Groundwater depletion is one of the major problems in India because of population pressure, rapid urbanization, irregularity in precipitation and intensive use of groundwater for agricultural activity (Chatterjee et al. 2020). Regional-level groundwater storage depletion mainly 
depends on temporal responses from natural and artificial effects.

Groundwater represents a source of freshwater that can be withdrawn even during dry season compared to problematic use of surface waters which may have little or no water during lean seasons. Moreover, groundwater is usually less polluted than surface water. On the other hand, abstracting groundwater is technically more demanding and expensive as in case of surface water. However, in some regions, such as India, safe surface water may no longer be available (Kundewicz and Döll 2009).

It is evident that groundwater is subject to stress with respect to both quantity and quality. For instance, many aquifers are being overexploited, especially, in semi-arid and arid regions. Groundwater recharge thus represents a significant factor which influences the groundwater withdrawal (Döll and Fiedler 2009). Groundwater recharge is connected to atmospheric, surface and subsurface components of the water balance and is sensitive to both climatic and anthropogenic factors, such as, precipitation land use/ cover change, and urbanization (Herrera-Pantoja and Hiscock 2008; Holman et al. 2009; Jyrkama and Sykes 2007; Mohan et al. 2018).

The increased water demand, especially in regions with limited surface supplies, and the continued deterioration of surface water quality are placing the groundwater resources under increasing stress. Water consumption can also significantly increase due to natural phenomena as well e.g. the novel coronavirus disease (COVID-19) which causes increasing washing hands more frequently. This subsequently raises sustainability concerns that are connected to sustainable groundwater planning and management (Vaux 2011; Jakeman et al. 2017). Meanwhile, recently several studies have been also conducted to improving the water consumption behavior (Salimi et al. 2019).

Geographic information systems (GIS) and remote sensing (RS) techniques are very useful for modeling groundwater depletion, recharge and stress zones (Anderson et al. 2015; Rodell et al. 2009; Famiglietti et al. 2011; Gleeson and Wada 2013; Voss et al. 2013; Castle et al. 2014; Da Costa et al. 2019; Das and Pal 2019a, b). In particular, satellitebased groundwater data provide a primary investigation of groundwater conditions. The National Aeronautics and Space Administration (NASA) Catchment Land Surface Model (CLSM) is one of the land components models which can be used for studying spatiotemporal changes in groundwater storage under terrestrial water storage from the global land data assimilation system (GLDAS) (Rodell et al. 2004). Different methods could be applied to study the groundwater stress; storage change as well as recharge e.g. WaterGAP global hydrology model (WGHM) (Döll et al. 2003).

Few studies dealt with the regional-scale groundwater storage change using gravity recovery and climate experiment (GRACE) data with correlated groundwater monitoring levels in India. Shamsudduha et al. (2012) tested groundwater storage change with GRACE data under basinscale dynamics of hydrologic systems for dry and wet season from 2003 to 2007 for the Bengal Basin in Bangladesh. They estimated GWS by deducting the contribution of changes in remaining terrestrial water stores including soil moisture, surface water, and ice and snow and also explained substantial increases in groundwater abstraction for lean monsoon irrigation. Dasgupta et al. (2014) studied the relationship between groundwater storage and soil moisture signature based on the GRACE data in order to observe the groundwater depletion in the Gangetic plain. It is noted that monthly, seasonal and annual hydrologic signals were considered for this analysis. Singh et al. (2017) calculated the spatial and seasonal variation of the surface water budget using the GRACE data during 2003-2012 and geospatial technology in the north-western region of India. It is observed that groundwater storage change and GRACE stipulated storage change loss was in the value range of $\pm 86.43 \mathrm{~km}^{3} / \mathrm{y}$ representing an average of 10 years of data.

Chinnasamy et al. (2018) developed the volume of groundwater recharge based on crop irrigation water use from water table depth of pre-monsoon and post-monsoon seasons for the hard rock area in the Udaipur district of Rajasthan. In addition, this study proved that the groundwater recharge can be estimated without needing a calibration of groundwater model. During the last decade, the information derived from RS technology provides tremendous potential for identification, monitoring, and assessment of water related applications, especially for regions with sparse in situ observations (Sharifi et al. 2019). Wakode et al. (2018) estimated natural recharge from the precipitation, actual evapotranspiration (ET), and surface runoff using RS and GIS techniques for the city of Hyderabad in India. The soil conservation service curve-number (SCS-CN) method was used for the calculation of urban water balance. It is an empirical approach-based rainfall-runoff model to calculate direct surface runoff from rainfall. This model indicates the relationship between rainfall and ground conditions (e.g., soil). The tropical rainfall measuring mission (TRMM) data were utilized for the estimation of accumulated rainfall during the research work. Han and Cao (2018) analyzed the phase differences between groundwater storage and groundwater level fluctuation for internal stress change in an aquifer-aquitard system in North China Plain aquifer. They also identified the episodic components of groundwater storage and groundwater level by the singular spectrum analysis (SSA). Mukherjee et al. (2018) studied the reduction in the groundwater base flow by groundwater storage depletion using remote sensing data in the adjoining Gangetic aquifer. It is observed that net Ganga river water reduce due to reduction because domestic water supply, irrigation water 
requirement, river transport, ecology and dense population. It is directly affecting impacting food production vulnerability of 100 million populations. Sridhar et al. (2019) assessed the total water storage based on the GRACE satellites for seven major river basins: James, Patuxent, Potamac, Rappahannock, Susquehanna, Western Shore, Eastern Shore, and York. The parameter-elevation regressions on independent slopes model (PRISM) precipitation, variable infiltration capacity (VIC)-simulated ET and moderate resolution imaging spectroradiometer (MODIS)-derived ET were utilized for total water storage change (TWSC) prediction of the watershed.

Singh et al. (2019) studied the impact of land water storage variation on agriculture using the GRACE and GLDAS data in India. The results showed that the runoff was very high for the monsoon season and accumulated rainfall was $76.58 \mathrm{~cm}$ for the year 2015 over India. Singh and Kumar (2019) performed mean annual per capita water availability (PCWA) change analysis for demographic control under 1.5, 2.0 and $3.0^{\circ} \mathrm{C}$ levels of global warming over India. Based on the results, the PCWA will decrease for all the warming scenarios across India. The results also showed that the population and mean annual rainfall were very sensitive factors for policies that aim to manage water scarcity. Bhanja et al. (2020) studied usable groundwater storage based on the GRACE satellite data with correlated in situ data for water security, drinking water supply, food production at the state level in India. They used 3907 groundwater monitoring wells for the analysis. Chatterjee et al. (2020) assessed the groundwater potential recharge based on groundwater storage change using the GRACE data for sustainable groundwater management of northeast India. This study indicated the terrain suitability for groundwater recharge based on hydrogeology and terrain parameters with integrated average monsoon recharge.

These recent advances in groundwater stress analysis methods have improved our understanding of groundwater availability to meet current water demands (Richey et al. 2015; Herbert and Döll 2019). Based on the available literature, it is noticeable that there is scope for the development of a framework for district-wise future groundwater planning under climate uncertainty. Therefore, this study aims to analyze the identification of district-wise groundwater stress zone (GWSZ) based on biophysical and hydrological parameters by AHP method. The study also aims to spatiotemporally assessment of the groundwater storage changes under terrestrial water storage from 2000 to 2014 corresponding with observed groundwater level and groundwater recharge in the Indian state of West Bengal. Additionally, the study focuses on an analysis of the spatiotemporal surface soil moisture, root zone soil moisture and profile soil moisture for identification of the water stress areas. Present research works considered only pre-monsoon season, which implies major water problem in this period. Eventually, this study provides the real problem-solving framework for improved district-wise sustainable groundwater management.

\section{Study area}

West Bengal is the $13^{\text {th }}$ largest state of India with total area $88,752 \mathrm{~km}^{2}$. It extends from the Himalaya to the Bay of Bengal. It is a dense river network-based state. The Major River is Bhagirathi-Hooghly distributaries of the Ganga River and length is $260 \mathrm{~km}$ long. There are various tributaries like Mayurakshi, Ajoy, Damodar, Dwarakeswar, Shilabati, Rupnarayan, and Kangsabati in the middle to lower part of the state. There is no any hydraulic structure across the Ajoy and Dwarakeswar Rivers have for water control in the river system. The upper part has a Mahananda River originates from the Himalayas at an elevation of $2100 \mathrm{~m}$ above mean sea water level and enters Bangladesh near Tentulia Panchagarh district. It is a trans-boundary river that flows through West Bengal, Bihar, in India and Bangladesh. Although there is water scarcity problem in this state because of the sedimentation that considered the major problem in the river system, the sedimentation load has been increased and decreased by human activities. Thus, these kinds of problem affected in the terrestrial water storage system under changing climatic conditions.

It is divided into nine physiographic provinces. However, West Bengal is divided into nineteen districts (Fig. 1). Now it is included four extra districts like Kalimpong, Alipurduar, Paschim Bardhaman and Jhargram. It has a common border with Nepal, Bhutan and Sikkim (India) in the north, Assam (India) and Bangladesh in the east, Bihar (India) in the west and Orissa (India) in the southwest. It has three divisions, namely Bardhaman division, Presidency division, and Jalpaiguri Division. It has included the Darjeeling Himalayan hill region, the Ganges delta, the Rarh region and the coastal Sundarbans. The Sundarbans is a mangrove dominated area in the delta and one of the three largest single tracts of mangrove forest of the world (Islam and Gnauck 2009). Sundarbans has four protected areas under United Nations Educational, Scientific and Cultural Organization (UNESCO) World Heritage Sites (Sundarbans National Park, Sundarbans West, Sundarbans South and Sundarbans East Wildlife Sanctuaries). The Sagar Island one of the big island in West Bengal under part of Sundarbans. It is a place of Hindu Pilgrimage lying on the Continental Shelf of Bay of Bengal about $100 \mathrm{~km}$ south of Kolkata. However, elevation values vary from 0 to $4000 \mathrm{~m}$. The highest day temperature values between 38 and $45^{\circ} \mathrm{C}$ and the average temperature is $30^{\circ} \mathrm{C}$. It is observed that the rainy season showed between July to end of the September and the average rainfall is $175 \mathrm{~cm}$. It is also observed that heavy rainfall $(>250 \mathrm{~cm})$ showed in the 


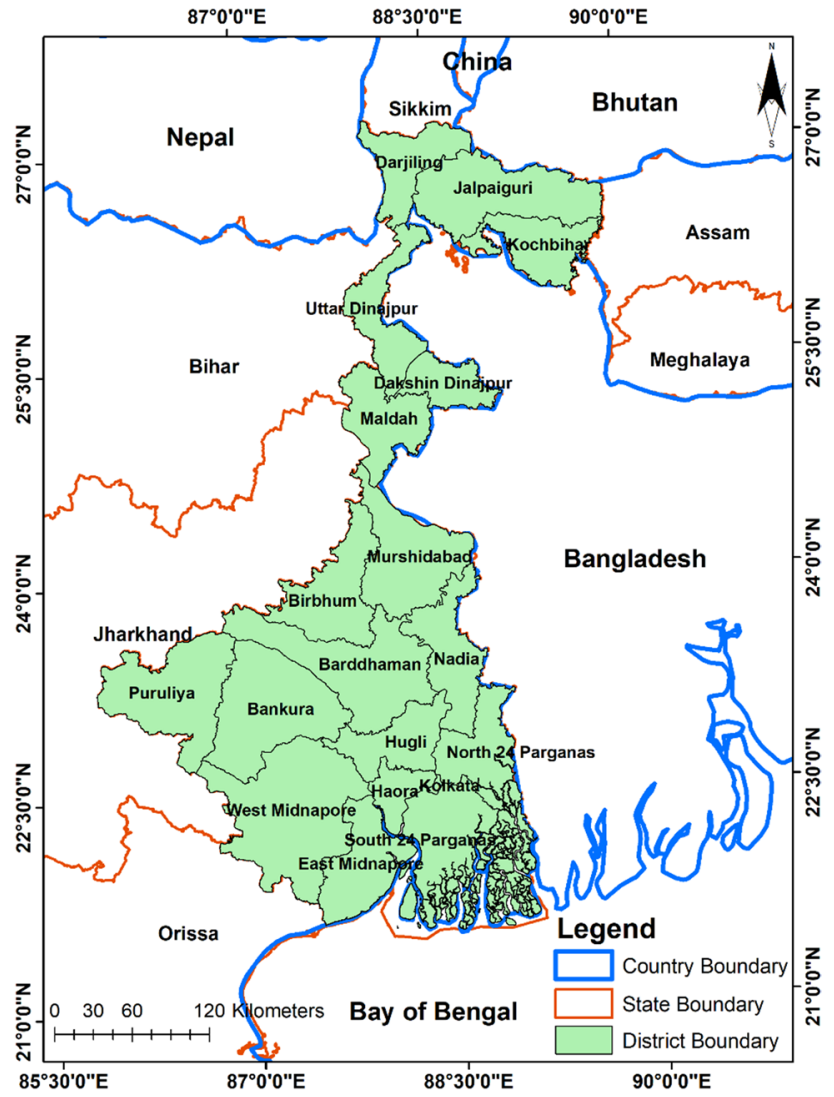

Fig. 1 Location map of the study area (West Bengal)

district of Darjeeling, Jalpaiguri and Cooch Behar. It also shows the common occurrences of drought conditions in the district of Bankura and Purulia. Besides, this state $88 \%$ covers by cultivable area and cropping intensity are $177 \%$. It is the largest producer of rice and the second-largest producer of potatoes in India. However, this state is also the first rank in freshwater fish production. Thus, sustainable water resources planning (surface water and groundwater) are very important for future water management. The detailed physiographic information is available in Bandyopadhyay et al. (2014). The present research work considered only old nineteen districts.

\section{Material and methodology}

Surface soil moisture, root zone soil moisture, profile soil moisture, terrestrial water storage, groundwater storage data are collected for the period of 2000 to 2014, from the Global Land Data Assimilation System (GLDAS) Catchment Land Surface Model L4 daily $0.25 \times 0.25$ degree V2.0 (https:// disc.gsfc.nasa.gov). The GLDAS is an ingest satellite, ground-based, and model outputs for water resources applications. These data were collected from NASA GLDAS-2 catchment land surface model (CLSM). The GLDAS-2 CLSM model-based data were directly utilized for districtwise spatiotemporal changes of soil moisture (SM), terrestrial water storage (TWS) and groundwater storage (GWS). Furthermore, one can mention that the modeled hydrological components contain some degree of uncertainties, and observational data from satellites might be an acceptable alternative in near future when a more robust data will be available, and therefore GWS data with less uncertainty can be obtained. However, inverse distance weighting (IDW) interpolation technique was used in order to generation the annual-basis spatiotemporal TWS and GWS maps. The maximum, minimum and mean values of the district-wise GWS were calculated from the generated maps for 2000 to 2014. Soil moisture represents the amount of water between the soil particles. It is a very significant variable because of evapotranspiration estimation; irrigation water can be calculated through water balance techniques ( $\mathrm{Li}$ et al. 2019). It is a very important indicator for crop cultivation challenging to calculate from coarse spatial resolution satellite images. It is also an important variable for health or stress on the land surface ecosystem. Thus, land surface model data can be estimated as long-term spatiotemporal changes in soil moisture. In the present study, the GLDAS-2 CLSM model was used for spatiotemporal soil moisture changes to identify the water stress areas. High soil moisture values spreader over the central, north-eastern and southern India during the last few decades. Lower values have been observed over the Indo-Gangetic plains, whereas the lowest values have been noted over the western arid region. The nature of the heterogeneous distribution of soil moisture in changing spatial scales is noticed from the climatic mean. However, three kinds of soil moisture like surface soil moisture, root zone soil moisture, and profile soil moisture are considered for the analysis. Surface soil moisture indicates the dry or wet soil in the topmost layer. It can be used for the analysis of the root zone soil moisture. Root zone soil moisture is very important for the regulation of water and energy budget. Profile soil moisture represents the standard deviation and the coefficient of variation significantly differs surrounded by farmland, forest land and grassland ( $\mathrm{Li}$ et al. 2019). It is noted that the variations of these three types of soil moisture indicate the predicting variation of precipitation, surface temperature, drought, and flood. Soil moisture data (surface soil moisture, root zone soil moisture, and profile soil moisture) was utilized to identify the water stress areas. Population data is collected for 1991-2011 from the Census of India and used for identifying the groundwater stress zones at the district level. Groundwater data (2012-2017) was collected from India-Water Resources Information System (India-WRIS), Central Ground Water Board, Irrigation and Waterways Directorate, Government of West Bengal. 
NASA GLDAS is a satellite and groundwater observation data product using the advanced land surface model and data assimilation techniques to estimated optimal fields of land surface states and fluxes (Rodell et al. 2004). Four land surface models (Noah, Catchment, CLM, and VIC) are available for GLDAS drives. However, GLDAS-2 product is a couple by MODIS based land surface parameters and the model simulations are also forced by global meteorological forcing data. Thus, this dataset is very significant for district-wise water resources management considering climate uncertainty. This methodology focuses on district-wise spatiotemporal groundwater storage change under terrestrial water storage using GLDAS Catchment Land Surface Model because these kinds of data are available in this model. This study is included two objectives: (a) the spatiotemporal soil moisture change for identification of water stress areas, (b) identification of groundwater stress zones and spatiotemporal groundwater storage change for the district level.
However, the district-wise TWS and GWS are calculated for how much water is available for future water management. Finally, GWS data evaluated with the corresponded observed groundwater level and groundwater recharge data to support the accuracy of the obtained results. The overall methodological framework is shown in Fig. 2.

\section{Groundwater stress zone (GWSZ)}

The groundwater stress zones (GWSZ) are very important for future groundwater planning and management purposes. Ten biophysical and hydrological parameters [i.e., terrestrial water storage (TWS), groundwater storage (GWS), surface soil moisture (SSM), root zone soil moisture (RZSM), profile soil moisture (PSM), canopy water evaporation (CWE), direct evaporation from bare soil (DEBS), potential evaporation rate (PER), plant canopy surface water (PCSW), and soil temperature $(\mathrm{ST})]$ are considered for the generation

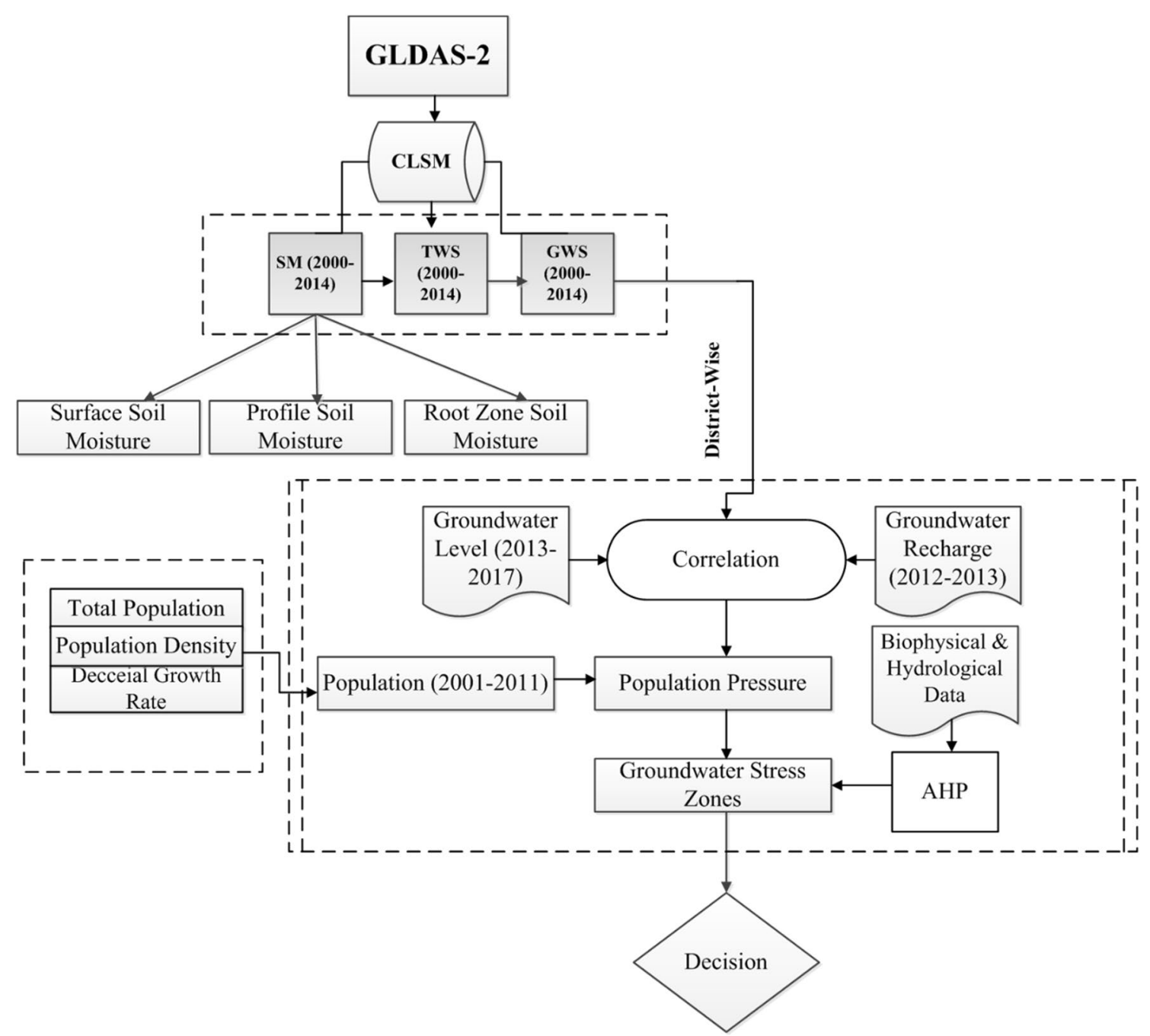

Fig. 2 Overall methodological framework 
of GWSZ from GLDAS using analytic hierarchy process (AHP) by GIS techniques. The AHP method mainly developed based on the theory of prioritization from human judgments by Saaty $(1980,1990)$. The AHP is a structured technique for analyzing complex decisions and quantifying the weight of decision criteria. Individual expert opinion is very important to estimate the relative magnitudes factors by pairwise comparison matrixes. The pair-wise comparison matrix is evaluated into two criteria by $1-9$ scale: (i) a criterion is precisely as significant of $\mathrm{B}$ criteria, then the index is 1, (ii) a is more dominant than $\mathrm{B}$, the index is 9 . All row values are filled into a cross matrix and diagonal matrix filled only value of 1 . However, multiple decision criteria are involved when the selection of one alternative. It is a powerful multicriteria decision making techniques (Torres-Rua et al. 2016) to delineate district-wise GWSZ. It should be mentioned that all parameters have direct and/or indirect impact on the groundwater system.

GWSZ can be calculated as (Dhar et al. 2015):

$\operatorname{GWSZ}_{i, j}=\sum_{k \in F} W_{k}\left(\sum_{l \in S_{k}} w_{l}^{k} \chi_{A_{l}^{k}}\left(\left.C_{i, j}^{v}\right|_{k}\right)\right)$,

where index $(i, j)$ denote row column location of a pixel; $F$ denotes the set of all features $(F), K$ denotes elements of features set; $S_{k}$ denotes set of sub-features for $k$ th feature; $l$ denotes element of sub-feature set; $W_{k}$ normalized weight of $k$ th feature; $w_{l}^{k}$ denotes normalized weight of $l$ th sub-feature for kth feature; $\left|C_{i, j}^{v}\right|_{k}$ denotes the class value of the cell $(i, j)$ for $k$ th feature; $A_{l}^{k}$ denotes the sub-feature interval, $X_{A_{l}^{k}}$ denotes the indicator function for $l$ sub-feature of $k$ th feature.

$\chi_{A_{l}^{k}}\left(C_{i, j}^{v}\right)=\left\{\begin{array}{l}1 \text { if }\left.C_{i, j}^{v}\right|_{k} \in A_{l}^{k}, \\ 0 \text { if }\left.C_{i, j}^{v}\right|_{k} \notin A_{l}^{k}\end{array}\right.$

In AHP (Saaty 1980) 1-9 scale is adopted for constructing judgment matrices.

The following steps are adopted for calculation of weights and consistency ratio (C.R.): development of judgment matrices (A) by pair-wise comparison.

Calculation of relative weight $W_{i}$ :

$W_{i}=\frac{\mathrm{GM}_{i}}{\sum_{m=1}^{N_{F}} \mathrm{GM}_{m}}$

where the geometric mean of the $i$ th row of judgment matrix is calculated as

$\mathrm{GM}_{i}=\sqrt[N]{a_{i 1} a_{i 2} \ldots a_{i N_{F}}}$.
Strength assessment of judgment matrix-based consistency ratio (C.R.) which is a comparison between consistency index (C.I) and random consistency index (R.C.I or R.I) (Piantanakulchai and Saengkhao, 2003; Youssef 2015). It is randomly generated reciprocal matrixes by $1 / 9$ scales. The consistency ratio (C.R.) is calculated as

C.R. $=$ C.I. $/$ R.C.I.

Consistency Index (C.I.) is evaluated as

C.I. $=\frac{\lambda_{\max }-N_{F}}{N_{F}-1}$

where the latent root of judgment matrix is calculated as

$\lambda_{\max }=\sum_{m=1}^{N_{F}} \frac{(\mathbf{A W})_{m}}{N_{F} W_{m}}$

where $\mathrm{W}$ is the weight vector (column). C.R. value less than 0.1 is acceptable for a specific judgment matrix. However, revision in judgment matrix is needed for C.R. $\geq 0.1$.

Same procedure should be followed for $w_{k}^{i}$ calculation. Finally, GWSZ map can be generated by using Eq. (1).

\section{Results}

\section{Spatiotemporal changes of soil moisture to identify the water stress areas}

Surface soil moisture (SSM) estimation is considered 0-20 cm in CLSM from GLDAS2 (Fig. 3). The district-wise soil moisture (SSM, RZSM, and PSM) data is extracted through the GIS platform. The high level of SSM shows that Uttar Dinajpur, Birbhum, Burdwan, Bankura, North 24 Parganas, South 24 Parganas and Howrah for 2005 compare to another year. In 2014, SSM is 5.77, 5.68, 5.64, 5.94, 5.60, 5.45 and $6.62 \mathrm{~kg} /$ $\mathrm{m}^{2}$ for above indicated seven districts of West Bengal, and it depends on precipitation and vegetation cover. Very high vegetation/forest covers conduct to more organic ground cover to help secure the SSM from evaporation. It is observed that a high level of RZSM for 2005 comes under these districts because it depends on SSM. PSM represents an integral understanding of soil moisture dynamics based on the depth of layers. The deeper layer significantly influences the SSM. Moreover, SSM is a key role for crop cultivation purpose compare to other soil moisture. Soil moisture can identify water stress because of the potential ability of plants to extract water. Soil moisture stress indicates the water in a plant's cell reduced to less than a normal level. However, low soil moisture indicates high water stress, and low water stress represents high soil moisture. The results show that few districts come under high water stress zones like Birbhum, Bankura, Purulia. The 


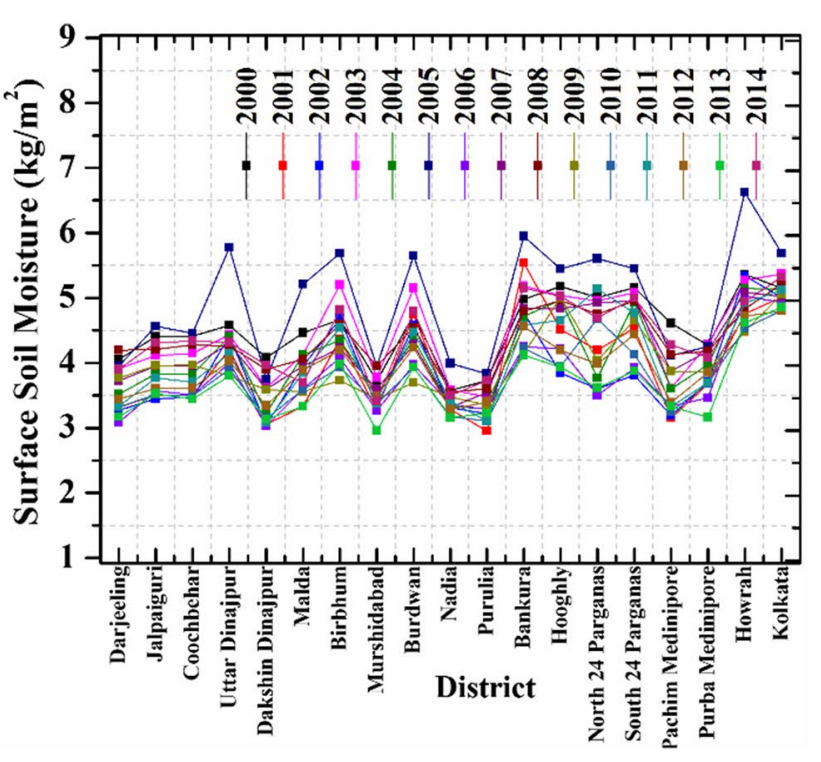

(a)

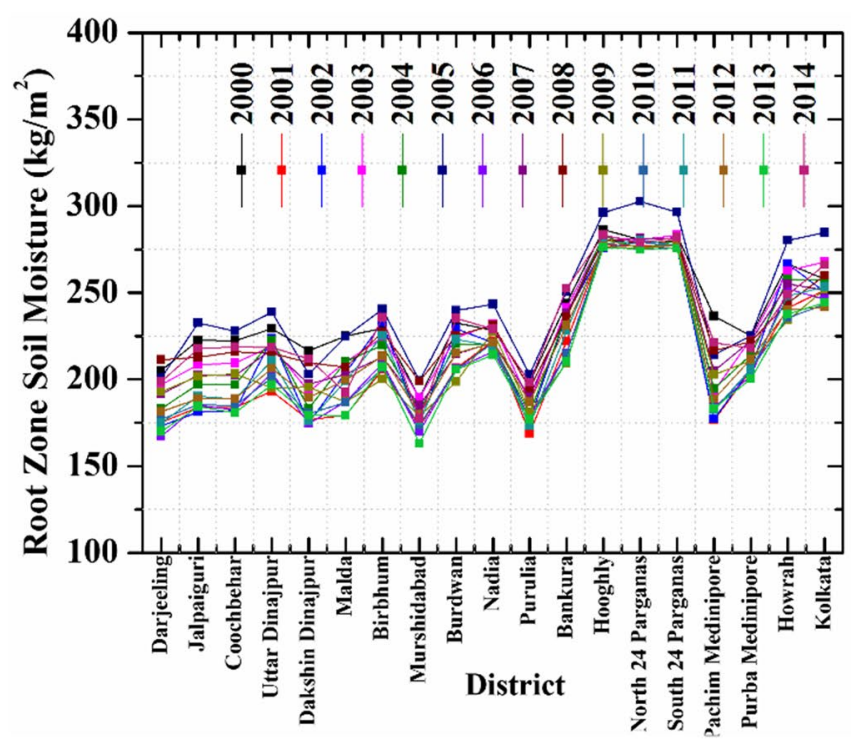

(b)

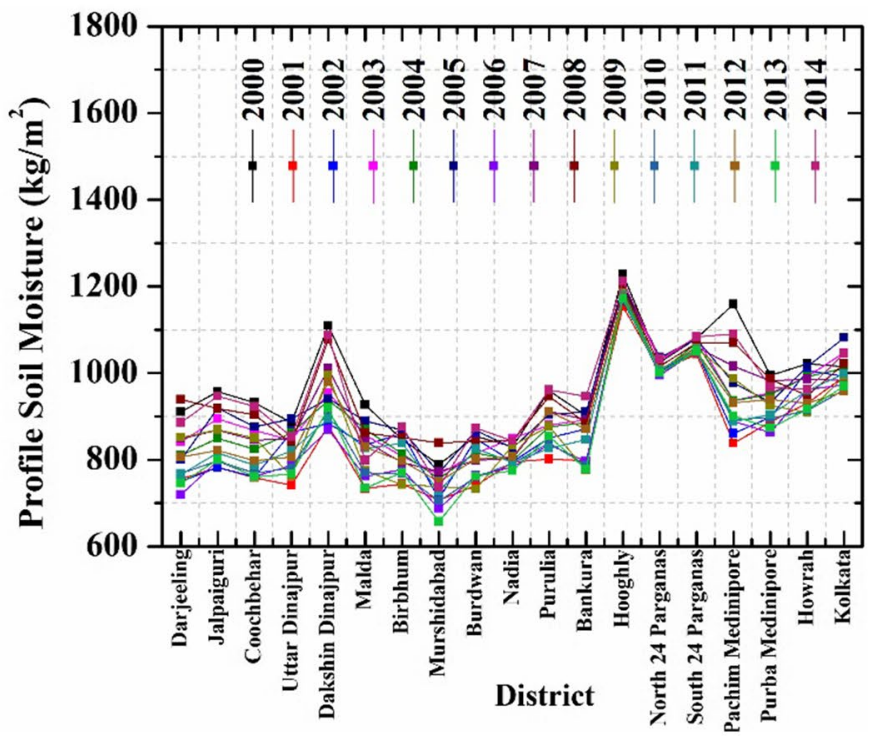

(c)

Fig. 3 District-wise spatiotemporal changes of a surface, $\mathbf{b}$ root zone and $\mathbf{c}$ profile soil moisture from 2000 to 2014

average SSM values in these three district are $4.47,4.78$ and $3.38 \mathrm{~kg} / \mathrm{m}^{2}$ from 2000 to 2014 . The results also show that the Darjeeling, Jalpaiguri, Cooch Behar, Uttar Dinajpur, Dakshin Dinajpur, Malda, Nadia, Burdwan, and Hooghly come under moderate water stress zones.

\section{Spatiotemporal changes in terrestrial water storage (TWS)}

Terrestrial water storage (TWS) represents the summation of all water on the land surface and in the subsurface and stored in the vegetation, lake, and river water (Girotto and Rodell 2019). TWS indicates the surface water storages and SSM, RZSM, groundwater, ice, and snow water. It is significantly affected by the river water system in major river basins.

GLDAS2 CLSM data has been used to district-wise spatiotemporal variability changes for pre-monsoon in TWS (Fig. 4). The results show that the northern $(600-800 \mathrm{~mm})$, middle (800-900 $\mathrm{mm}$ ) and western (1000-1100 mm) parts have has low water comparing to another parts, because these areas come under high water stress zones. It is observed that these districts like Bankura, Birbhum, Purulia 
have low cultivation areas due to low precipitation and very high temperature. In Purulia, the government increased the number and storage capacity of tanks and ponds $(10,533)$ in surface flow schemes for agricultural and domestic purposes according to Minor Irrigation Census (2013-2014). The results also show that North 24 Parganas (1056 mm), South 24 Parganas (1125 mm), Purba Medinipore $(1100 \mathrm{~mm})$, part of the Paschim Medinipore (1281 mm), Darjeeling $(1196 \mathrm{~mm})$, and Jalpaiguri $(1077 \mathrm{~mm})$ have high water storage that might be happen due to the close connection of those districts to Himalaya and Bay of Bengal. The premonsoon maximum and minimum TWS show in the year $2000(1372 \mathrm{~mm})$ and $2010(597 \mathrm{~mm})$ in the whole state. It is also observed that surface water is the major problem because rivers have low water for the pre-monsoon season. Thus, these districts mainly dependent on monsoon rainfall for agriculture cultivation, although groundwater was also used for pre-monsoon cultivation purposes. Moreover, surface water and groundwater are also utilized for crop cultivation and domestic purposes at the district level. TWS is highly impacted by climatic variability and anthropogenic activities (Frappart et al. 2019). Thus, proper surface water planning and management are required due to changing climatic conditions shortly.

\section{Spatiotemporal changes in groundwater storage (GWS)}

The groundwater crisis is in alarming proportions into the world, especially in India. Groundwater plays a key role in the terrestrial hydrological cycle and in sustaining ecosystems as the largest reservoir of freshwater on Earth. It is becoming a strategic importance for global water and food security under global change due to its major resource of
Fig. 4 Spatiotemporal changes of terrestrial water storage for pre-monsoon season from 2009 to 2014
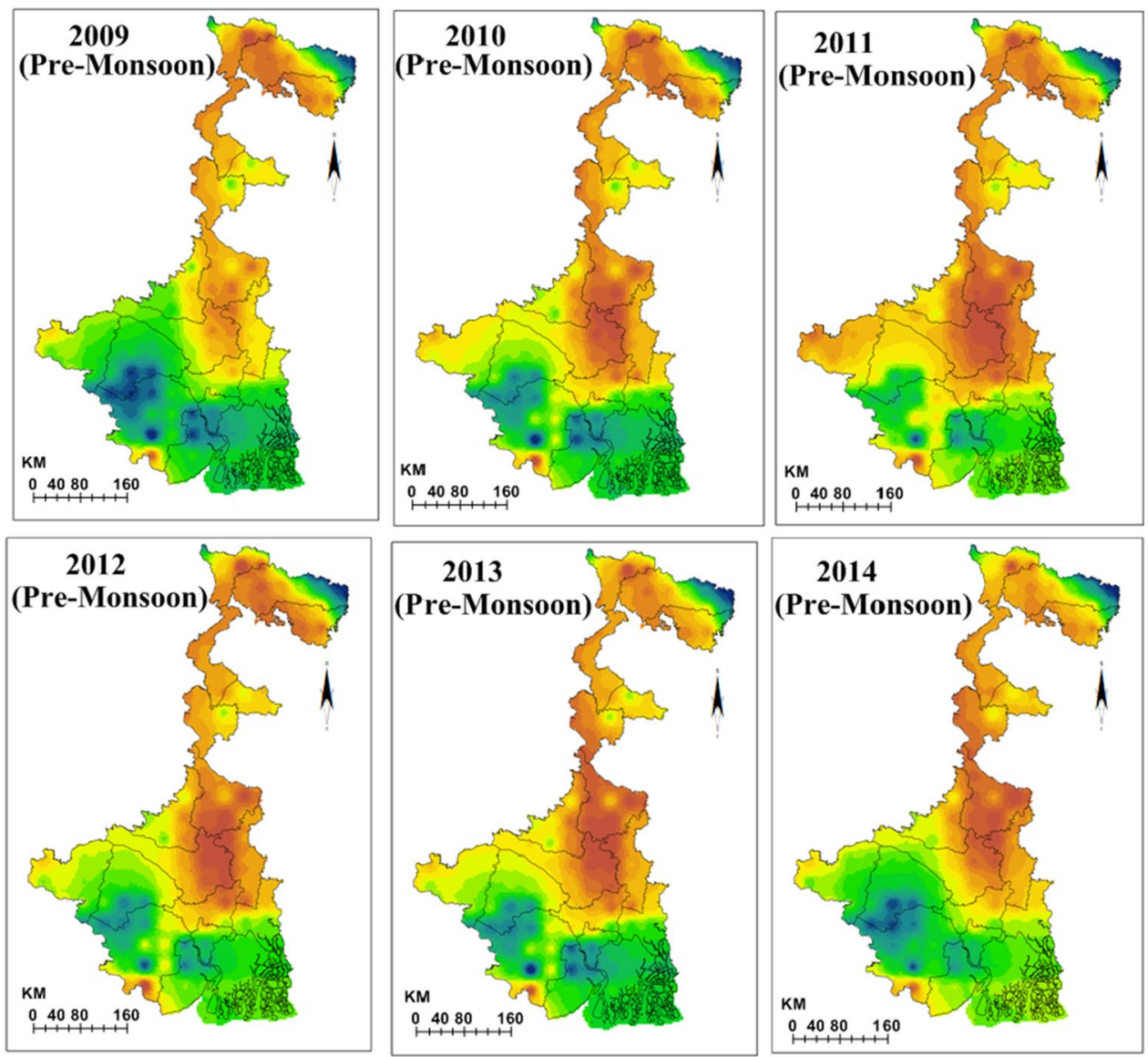

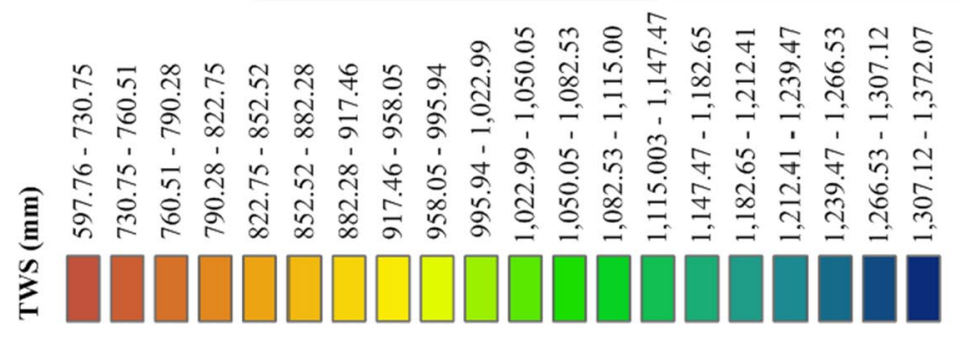


freshwater supply of the world population and the world food production. However, groundwater will be much more important resource when there is shortage in surface water. It is naturally replenished by surface water from rainfall, streams, and rivers. Major groundwater problems are water logging, sanitization, water table depletion, groundwater pollution and dying of aquifers. It can be seen that the groundwater declining rate is $1-2 \mathrm{~m} /$ year in many parts of India (Singh and Singh 2002). However, arsenic content is increased in the shallow aquifers of West Bengal reported by groundwater users. It is noted that the past three decades' groundwater exploitation and depletion is the major environmental problem in India addressing by Rodell et al. (2004). The nature of the groundwater problem in India is different because of different hydrogeological settings and socioeconomic situations (Shankar et al. 2011). It is also noted that the highest use of groundwater for agriculture purposes in India disclose by Shah (2009). Thus, water management is required for sustainable future water planning.

GLDAS2 CLSM (grid: $0.25^{\circ} \times 0.25^{\circ}$ ) is a land surface modeling based ingests and ground observational data. It can be directly utilized to calculate hydrological components (e.g. groundwater) for global to local scale. GLDAS2 CLSM data has been also used to district-wise spatiotemporal variability changes for pre-monsoon in GWS from 2000 to 2014 (Fig. 5). The results show that the northern to the middle portion of the state comes under low groundwater storage $(438.59-858.56 \mathrm{~mm})$. The results also show that high groundwater storage in the northeastern and south, southwestern parts of the state $(883.24-1152.44 \mathrm{~mm})$. The maximum part of the state covers by the high groundwater stress because of more use of groundwater for agricultural purposes. Thus, surface water is the major problem in West Bengal and that might be the reason of high usage of groundwater. It is observed that Jalpaiguri, small part of
Fig. 5 Spatiotemporal changes of groundwater storage for pre-monsoon season from 2009 to 2014
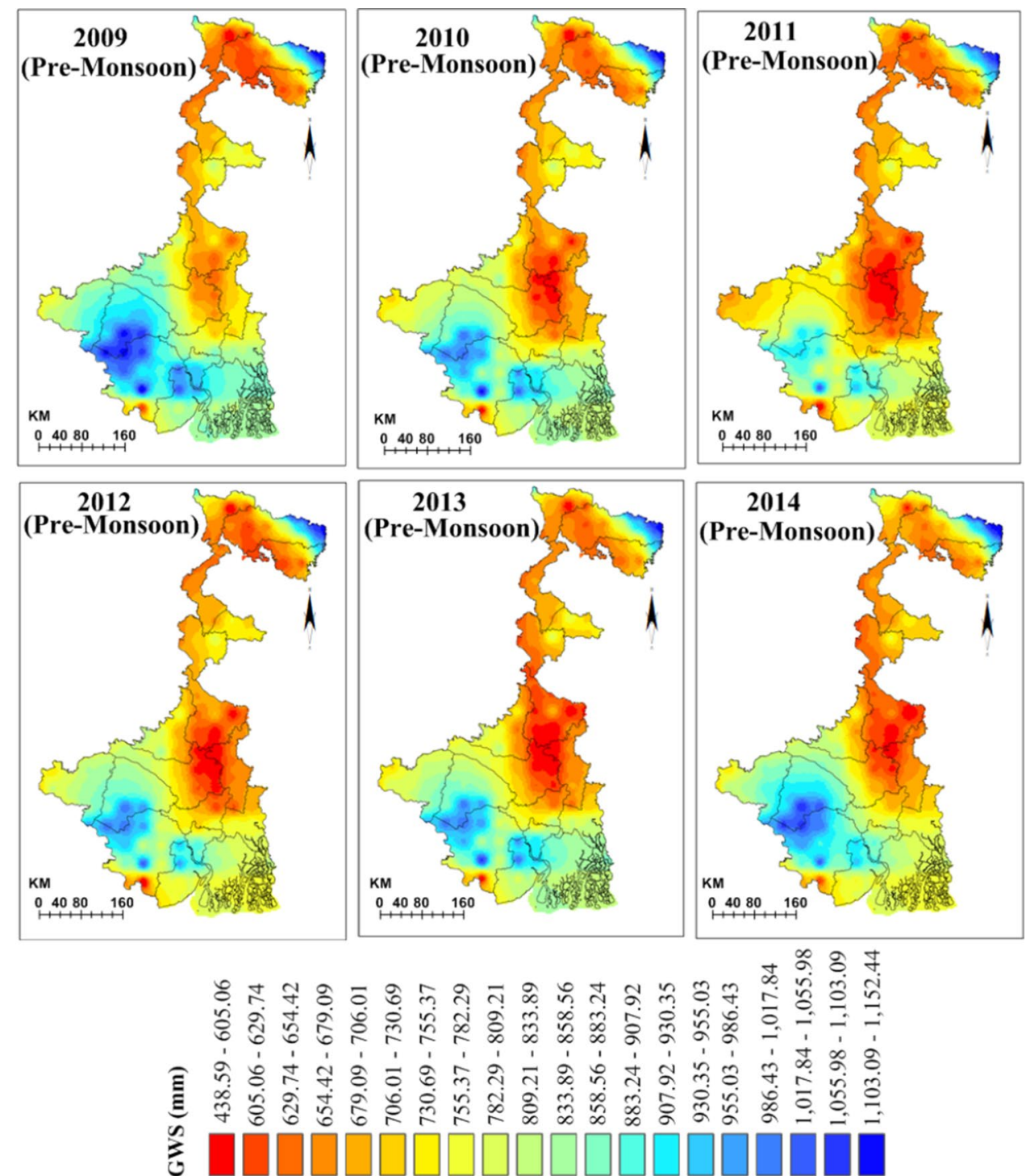
the Bankura, Paschim Medinipore and Purba Medinipore have high groundwater storage which is due to less agricultural productivities and having dense forest. The districtwise $\max$, min and mean of groundwater storage values presented in Figs. 6 and 7 from 2000 to 2014. It is observed that maximum groundwater storage values are shown in the Darjeeling, Jalpaiguri, Cooch Behar, Purulia, Bankura, Paschim Medinipore. Kolkata Municipal Corporation (KMC)

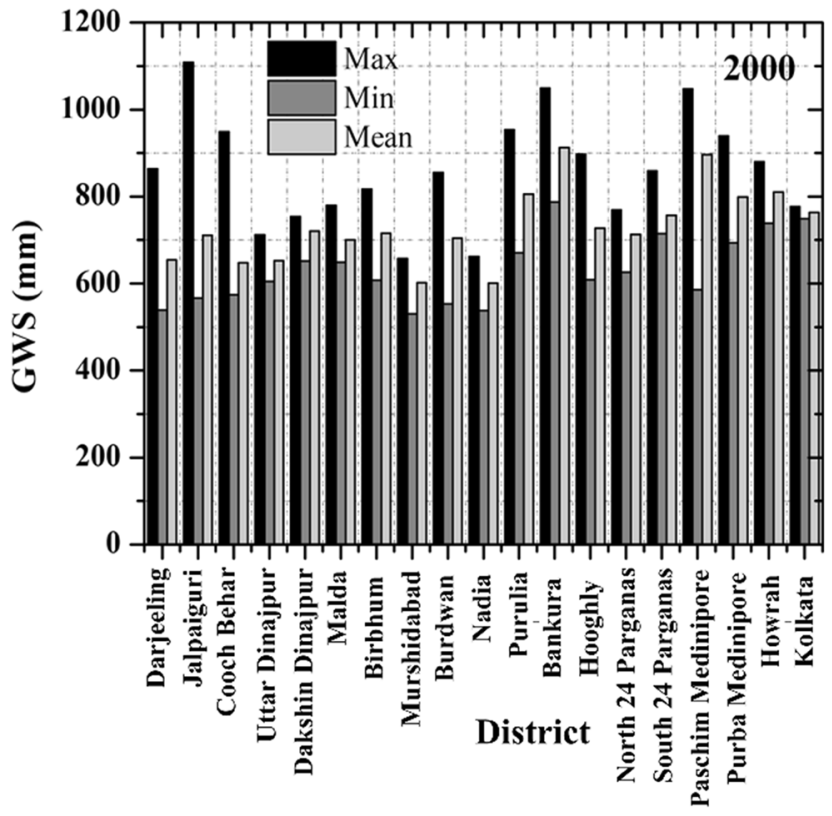

(a)

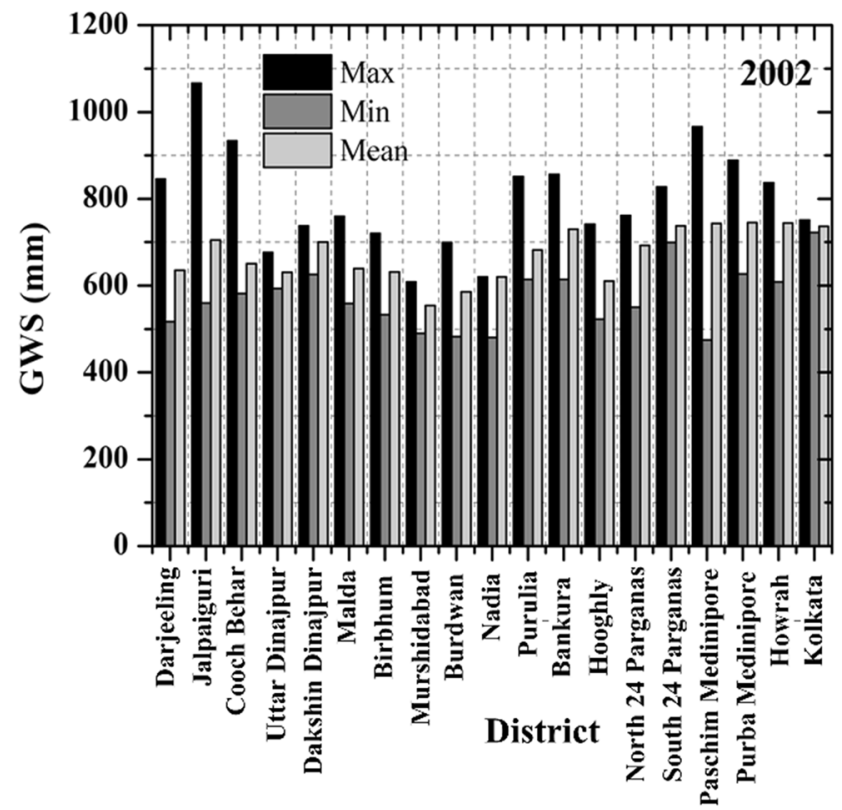

(c) is withdrawal heavy amount of groundwater. This district groundwater flow direction is toward the Bay of Bengal and the hydraulic gradient varies between $1-03 \mathrm{~m} / \mathrm{km}$. BaruipurSonarpur is one of the highest arsenic prone areas in the aquifer within $50 \mathrm{~m} \mathrm{bgl}$ under South 24 Parganas. Purba Medinipore has coastal sand dune in the Digha-Ramnagar area formed by sea contain fresh groundwater and groundwater depth between $6-8 \mathrm{~m}$ bgl from a near-surface aquifer.

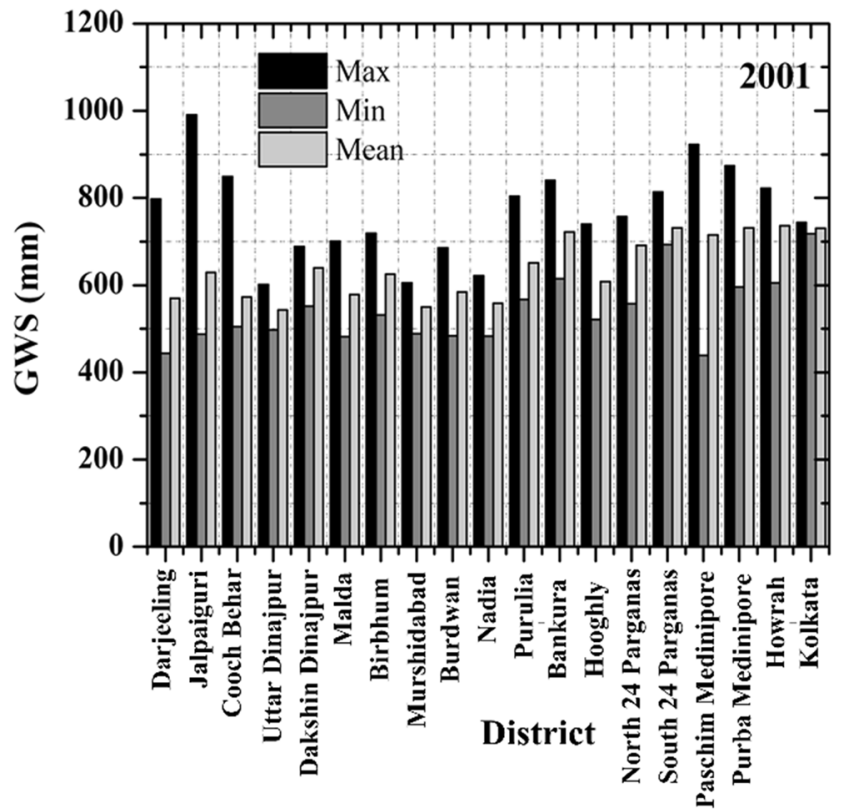

(b)

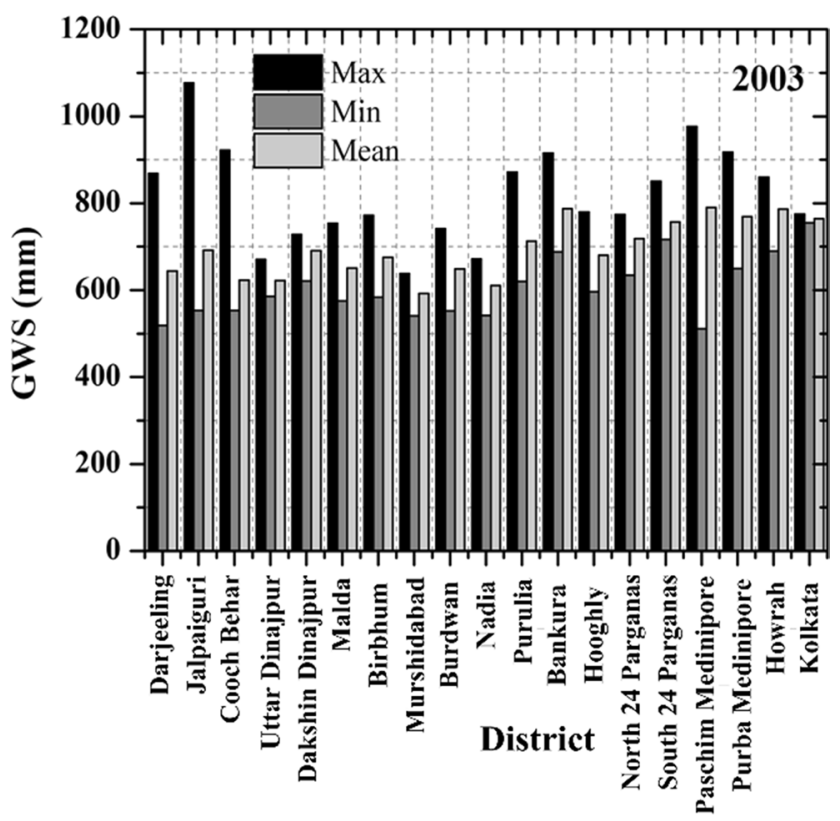

(d)

Fig. 6 District-wise max, min and mean values of groundwater storage for pre-monsoon season from 2000 to 2007 (a-h) 


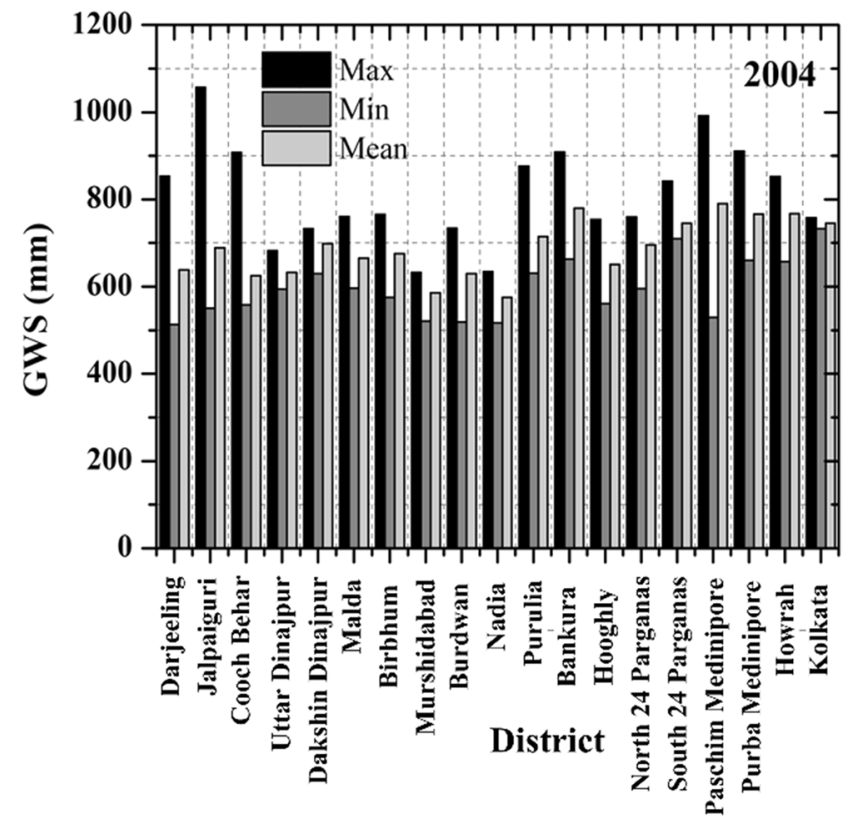

(e)

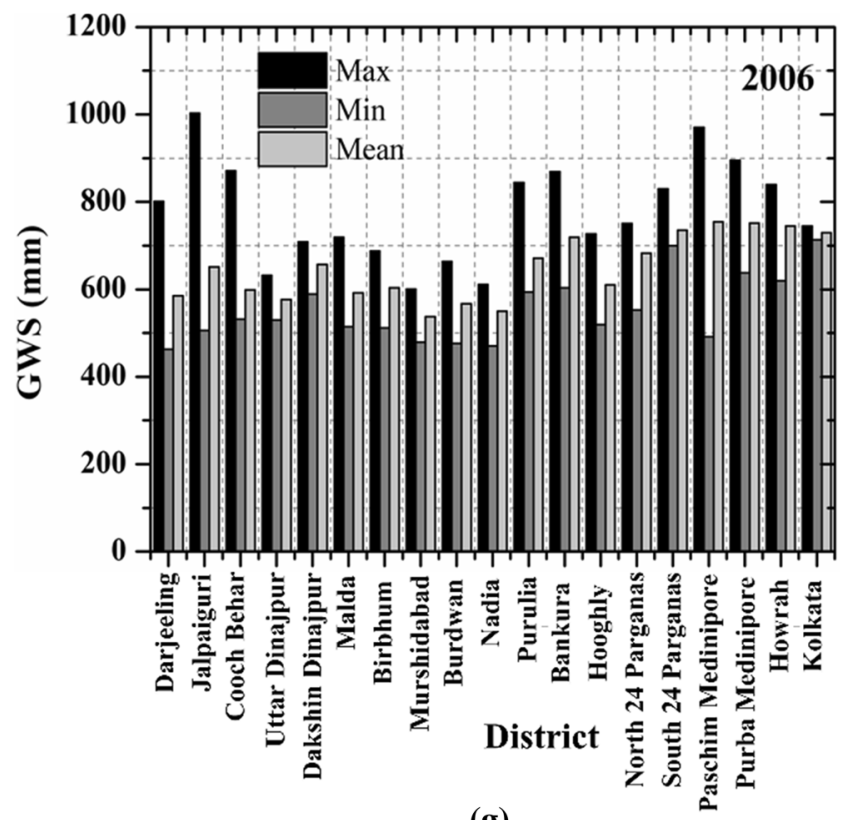

(g)

Fig. 6 (continued)

However, as above mentioned the population is very important for groundwater utilization. High population pressure is responsible for groundwater stress because per person required a minimum of $40-\mathrm{L}$ water per day. It is observed that the highest population is shown in the district of North 24 Parganas from 2001 to 2011 because of the Kolkata metropolice. It is also observed that high population pressure is shown in the district of Howrah and Kolkata according to population density (Fig. 8). It is found that the highest

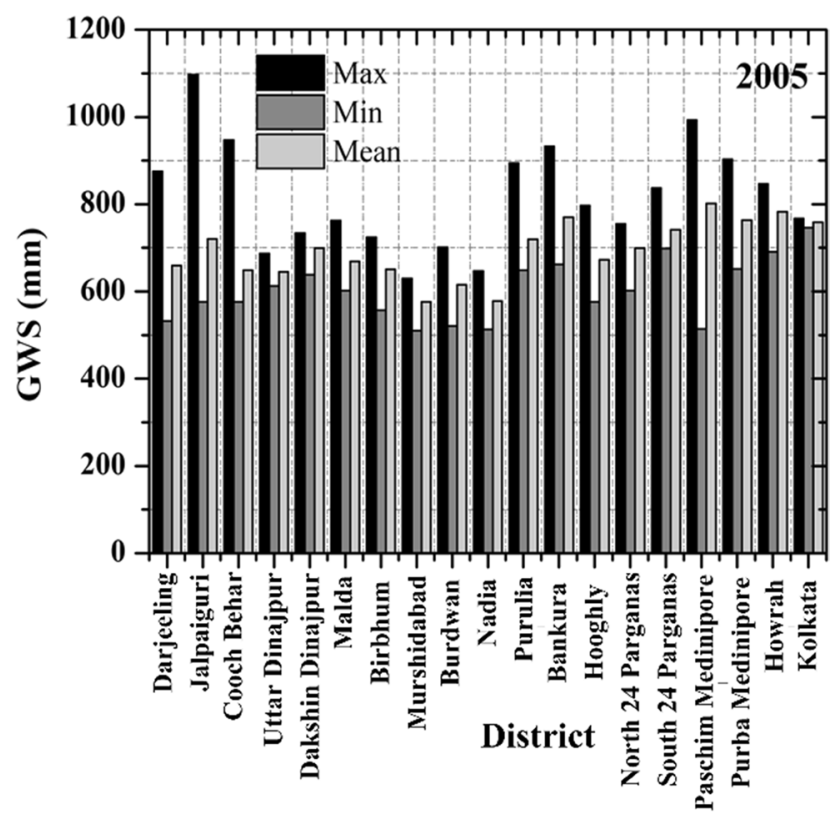

(f)

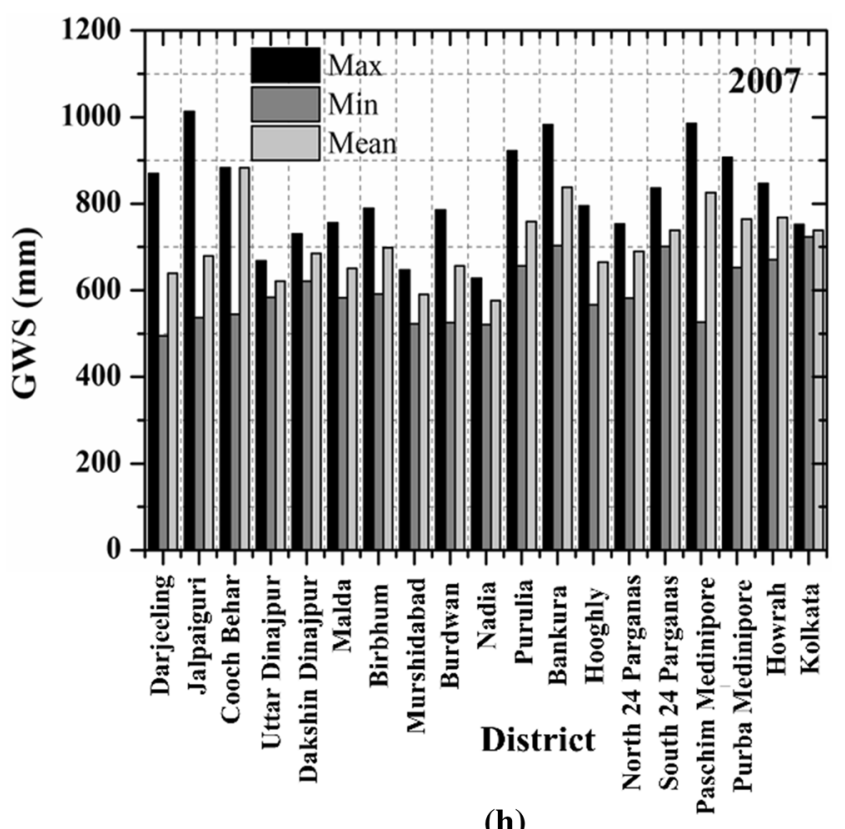

(h)

decennial growth rate shows in districts of Uttar Dinajpur, Malda, Murshidabad and North 24 Parganas from 1991 to 2011. Thus, population control is very important for groundwater saves the near future. Finally, groundwater storage has been validated by the groundwater level and groundwater recharge (Fig. 9). It is perceived that groundwater level and recharges very well justified the district-wise groundwater storage (e.g. Paschim Medinipore). 


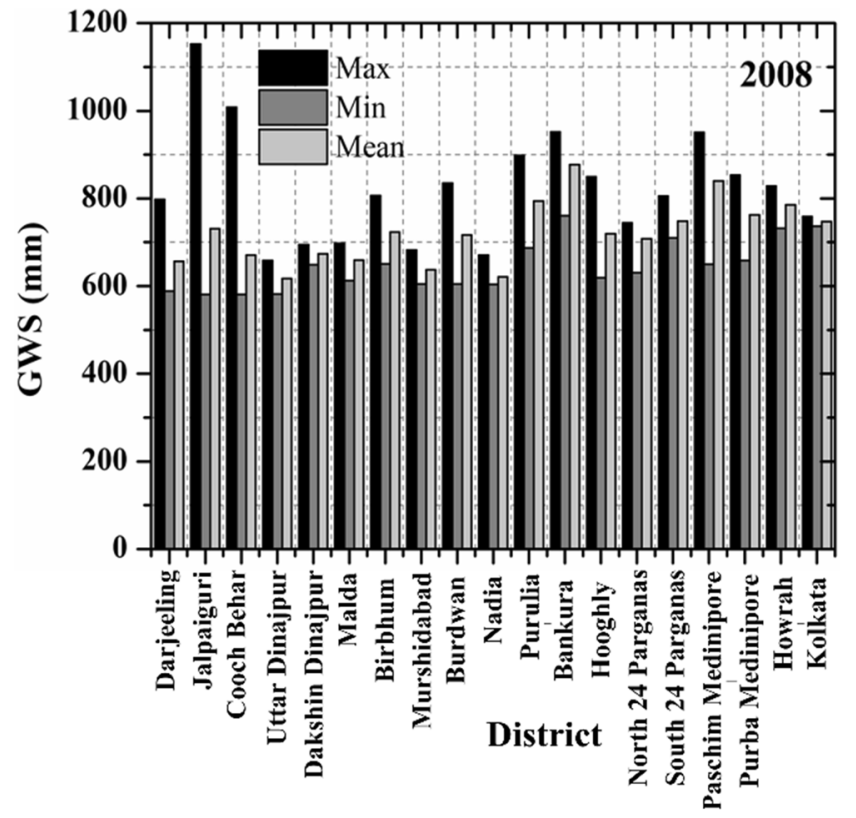

(a)

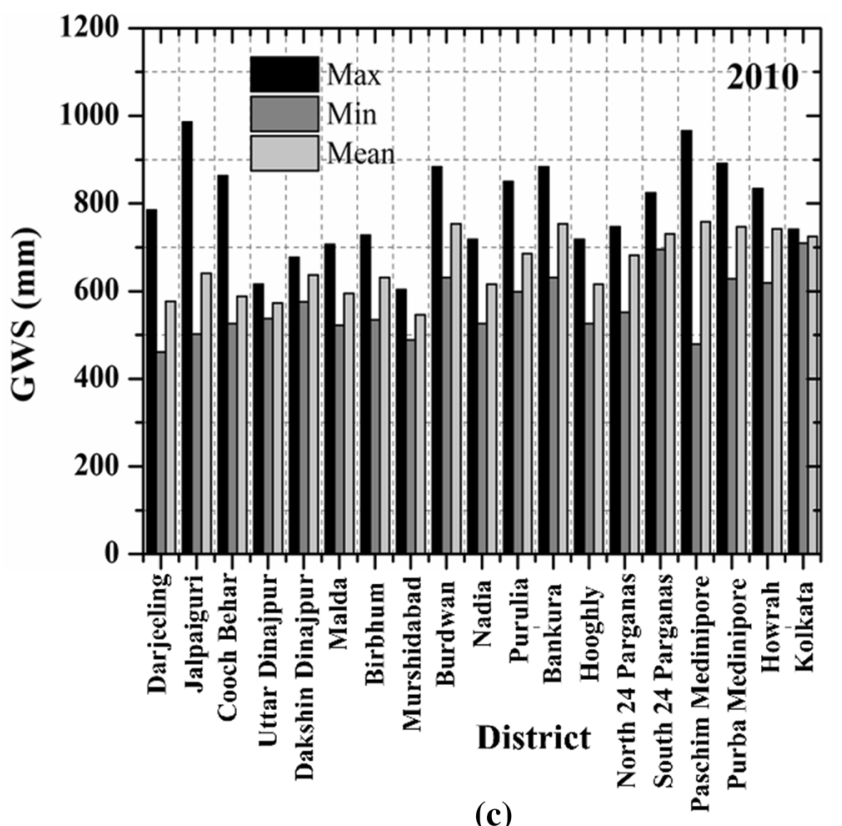

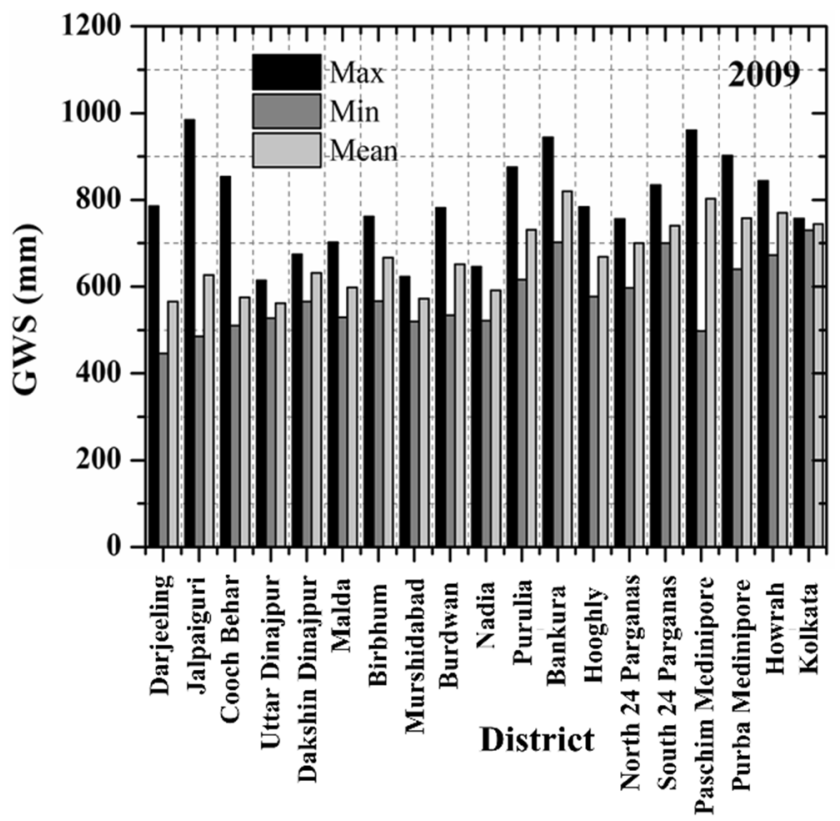

(b)

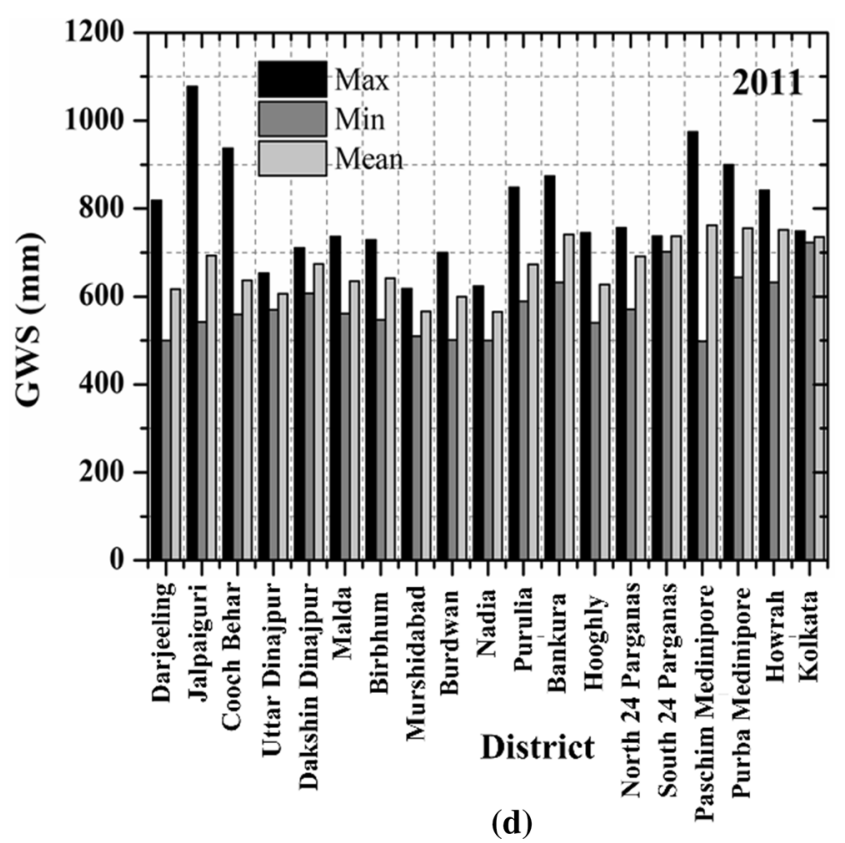

Fig. 7 District-wise max, min and mean values of groundwater storage for pre-monsoon season from 2008 to 2014 (a-g)

\section{Delineation of groundwater stress zones (GWSZ)}

The delineation of groundwater stress zones has been performed based on ten biophysical and hydrological parameters using the AHP method using the GIS technique tools. All biophysical and hydrological parameters like terrestrial water storage (TWS), groundwater storage (GWS), surface soil moisture (SSM), root zone soil moisture (RZSM), profile soil moisture (PSM), canopy water evaporation (CWE), direct evaporation from bare soil (DEBS), potential evaporation rate (PER), plant canopy surface water (PCSW), and soil temperature (ST) are calculated for pre-monsoon season of 2014 from the GLDAS2 CLSM. Soil moisture is very important for water stress areas under crop water management. Hydrological applications depend on soil and vegetation components. CWE indicates the interception by the canopy of a tree and evaporates from the leaves. PCSW representing the storage of rainwater on plant canopies that 


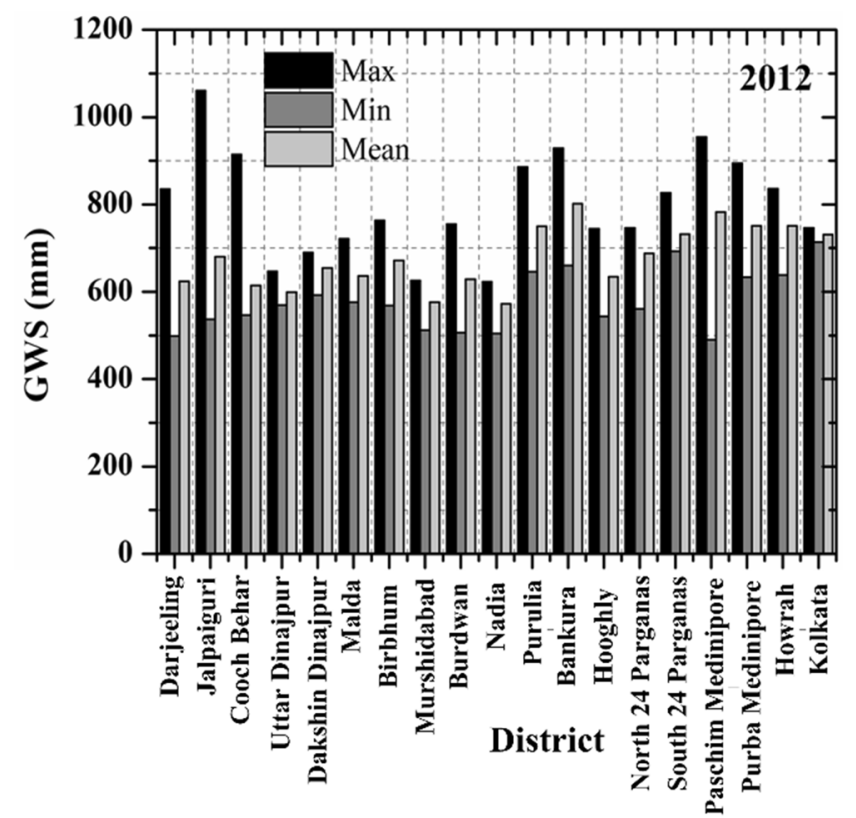

(e)

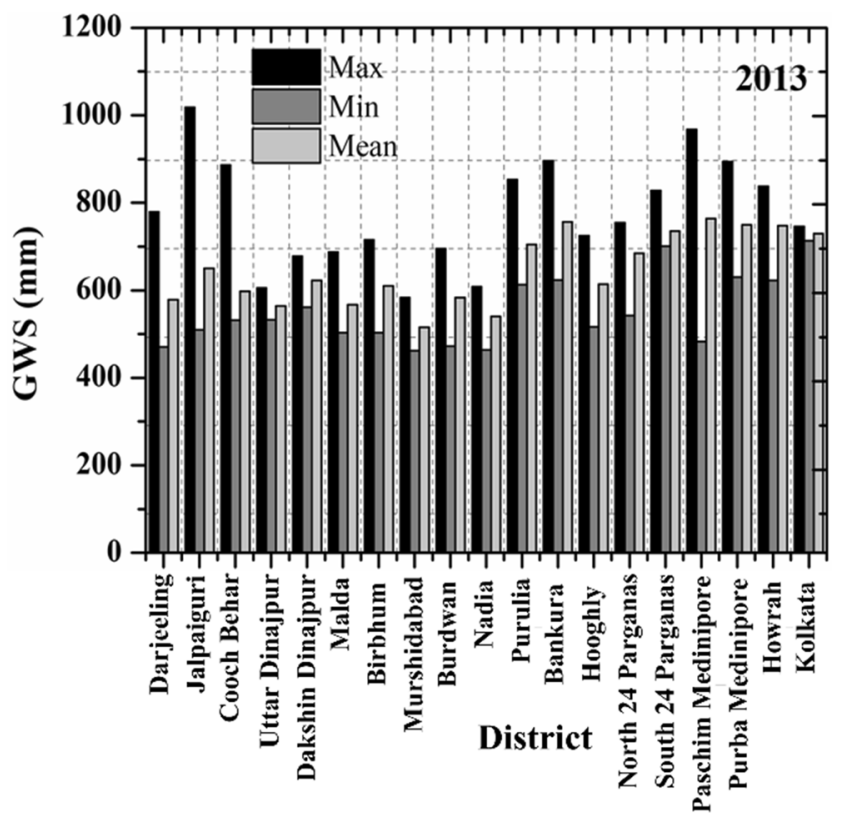

(f)

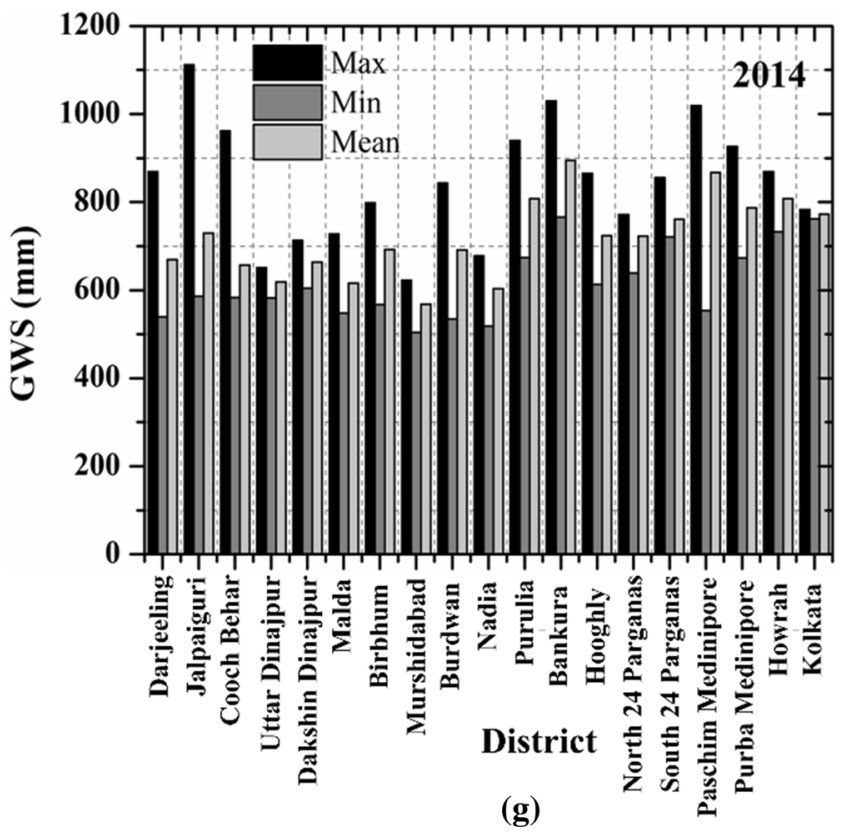

Fig. 7 (continued)

important implication for the energy and water balance of densely vegetated surface areas (Ghosh et al. 2016). DEBS represents a crucial pathway of water loss and does not contribute to crop production (Das et al. 2019). Moreover, all parameters are a direct and indirect impact on global to local groundwater system considering climate uncertainty (Figs. 10, 11). At first, all parameters are converted into raster format then the individual parameter is reclassified into sub-parameters based on normalized values through the AHP method (Table 1). The AHP based normalized value is calculated from the individual expert opinion weight assign for different parameters (Table ST1-ST10). Finally, all parameters are integrated by an overlay method based on AHP based normalized values to the generation of district-wise groundwater stress zone (GWSZ) for premonsoon of 2014 (Table 2). The resulting map has been classified into five classes (Fig. 12) (i) extreme (21.58\%), (ii) high $(22.42 \%)$, (iii) moderate (30.03\%), (iv) low (17.72\%) 


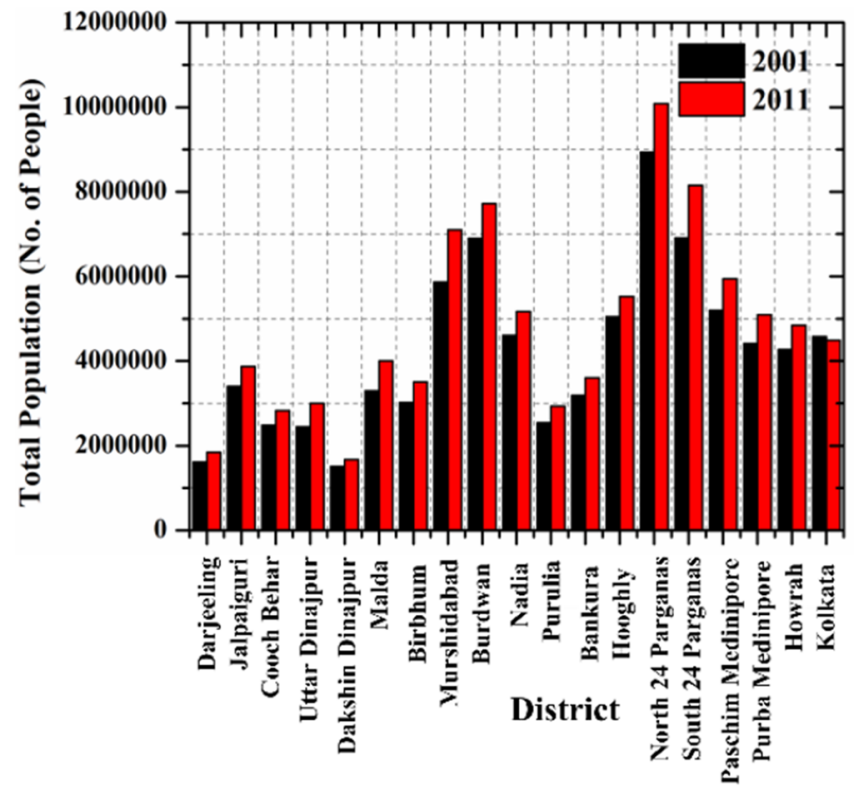

(a)

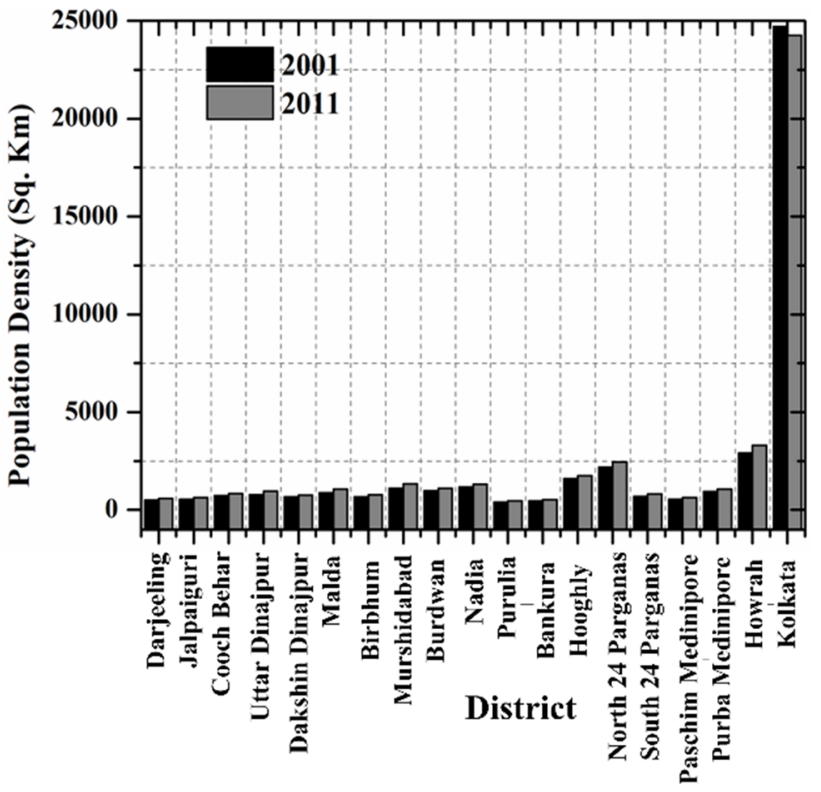

(b)

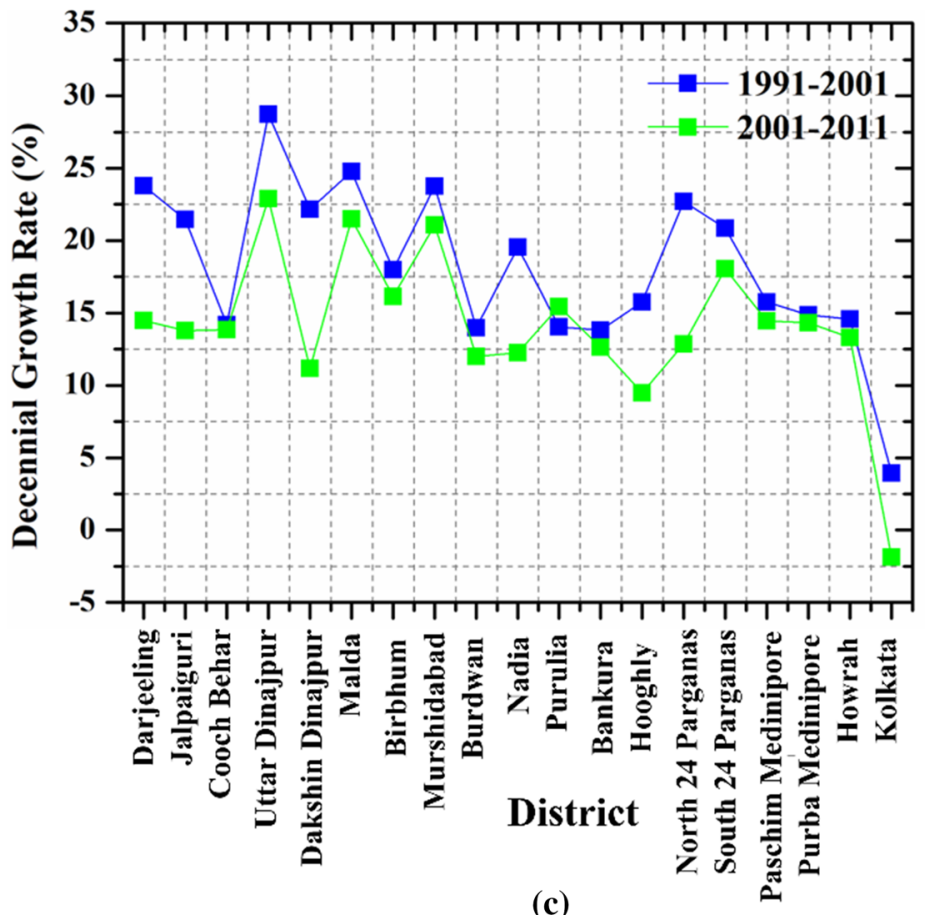

Fig. 8 District-wise graphical representation of the $\mathbf{a}$ total population, $\mathbf{b}$ population density and $\mathbf{c}$ decennial growth rate

and (v) very low (8.26\%). It is observed that high GWSZ showed in Birbhum, Murshidabad, Malda and small parts of the Darjeeling, Jalpaiguri, Cooch Behar, and Uttar Dinajpur. It is also observed that low GWSZ has shown in small parts of the Bankura, Paschim Medinipore, Howrah and Purba Medinipore because of high groundwater storage (1000-1152 mm).
Finally, GWSZ map very well justified by annual groundwater level and recharge values. It is found that Purba Medinipore shows a maximum average pre-monsoon groundwater level (18.31 mbgl) for 2013. The results indicated that Birbhum (12.71 mbgl), Murshidabad (10.81 mbgl), Burdwan (12.28 mbgl), Hooghly (16.43 mbgl), Purba Medinipore (15.92 mbgl) and Howrah (12.86 mbgl) yielded 


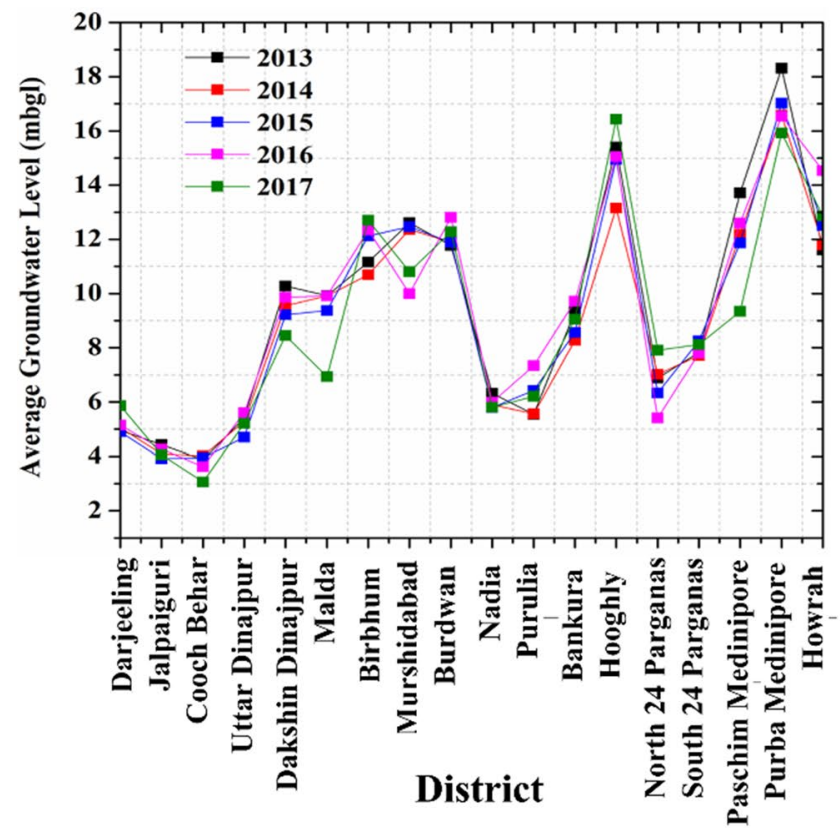

(a)

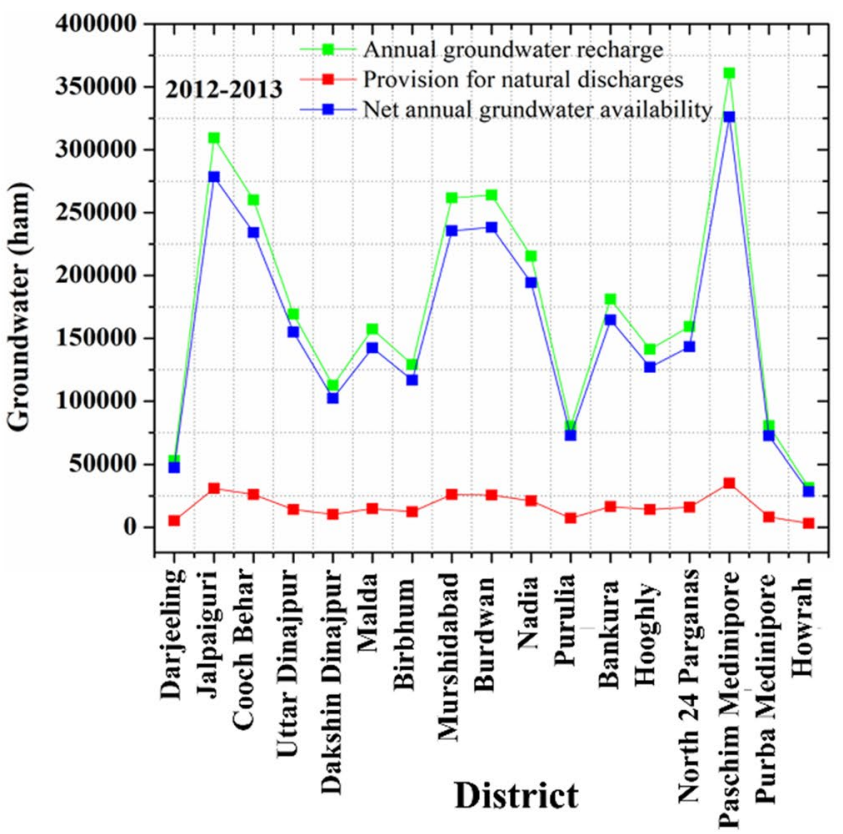

(b)

Fig. 9 District-wise spatiotemporal changes of pre-monsoon a groundwater level for 2013-2017, b groundwater recharge, discharge and availability based on observed data from 2012-2013

high average groundwater level compared to other districts for 2017. Moreover, the population data showed high correlation with the GWSZ map.

\section{Sensitivity analysis of GWSZ}

The sensitivity analysis indicates how various sources of the uncertainty contribute to output of a system performance. Ten biophysical and hydrological parameters are considered for this analysis by omitting individual parameters using AHP method (De Ridder 2001).

AHP-based normalized values are calculated from the previous literature and expert opinion and utilized for the generation of GWSZ by omitting individual features (Table ST11). The results show that the GWS has high impact on low and moderate GWSZs compared to another feature (Table 3). It is observed that terrestrial water storage (TWS), surface soil moisture (SSM), root zone soil moisture (RZSM), profile soil moisture (PSM), plant canopy surface water (PCSW), and soil temperature (ST) have higher impact on high and extreme GWSZs. It is also found that all parameters have a major impact on high and extreme GWSZ compared to other zones.

After that, most five sensitive parameters have been performed for inter-connectivity between dominant characteristic using Kendall, Pearson, and Spearman methods (Table 4). Kendall, Pearson, and Spearman are rank correlation coefficient methods that indicate an original association between two variables (Dhar et al. 2014; Liu et al. 2018). It is a non-parametric hypothesis test for a relationship between two variables. It is an efficient and robust way of identifying a monotone relationship. The values of these correlation coefficient methods range from +1 to -1 where +1 and -1 indicate perfect positive and negative relationships and 0 indicates no relationship. The district-wise pixel-based five parameter values are utilized for correlation coefficient analysis which is extracted concerning the centroid point of each district. The results show a similar relationship between the three methods for most sensitive groundwater stress parameters. It is observed that TWS, GWS, RZSM, PSM have negative strong relation with DEBS. It is also observed that all parameters (four) show a positive relation excluding DEBS. Thus, TWS, GWS, RZSM, and PSM have a very strong positive impact on groundwater scenarios. DEBS is an unfavorable parameter for the delineation of groundwater stress zones according to the correlation analysis.

\section{Discussion}

The groundwater is one of the nation's most important natural resources. More than $90 \%$ of the groundwater used for drinking purposes for the rural population. A huge amount of groundwater withdrawals represents the increasing in population and the limitation of surface reservoir. The 
Fig. 10 a SSM, b RZSM, c PSM and $\mathbf{d}$ CWE mapping from GLDAS data for pre-monsoon season of 2014

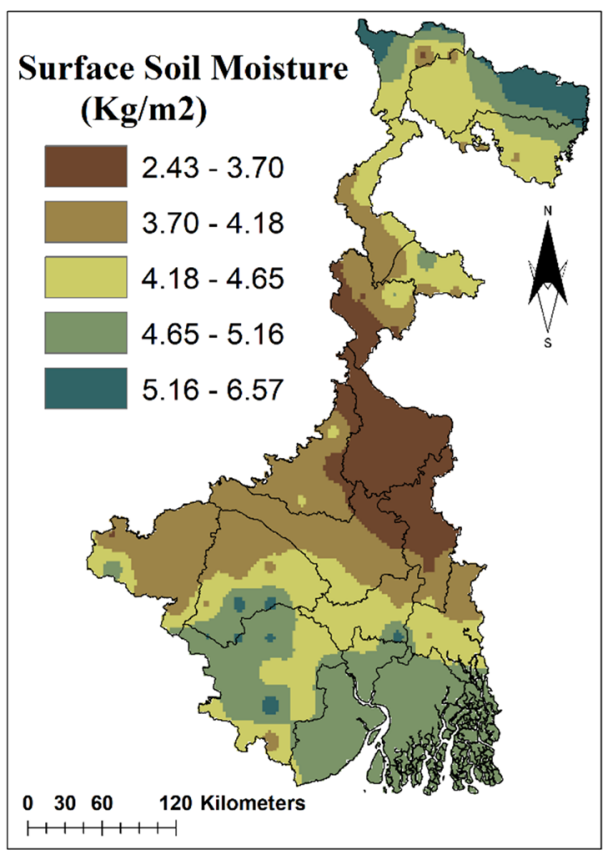

(a)

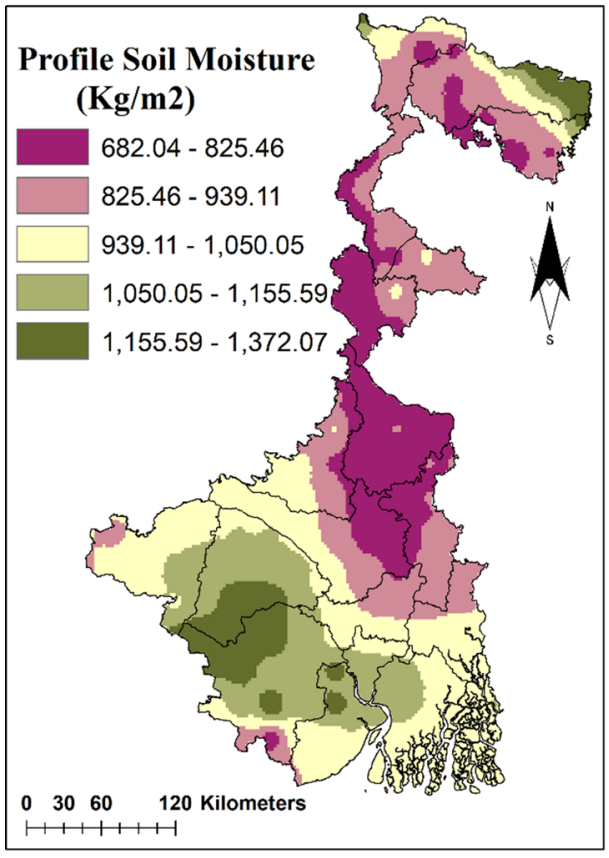

(c)

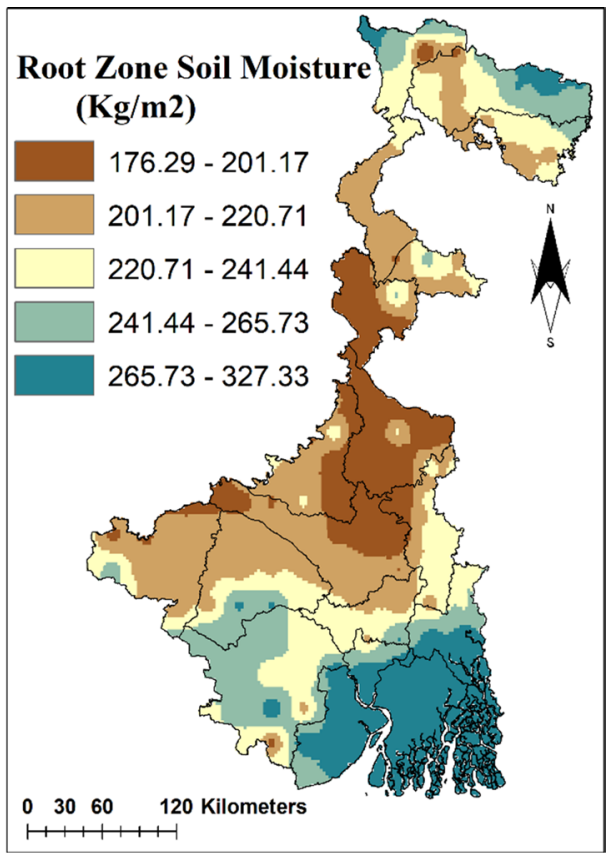

(b)

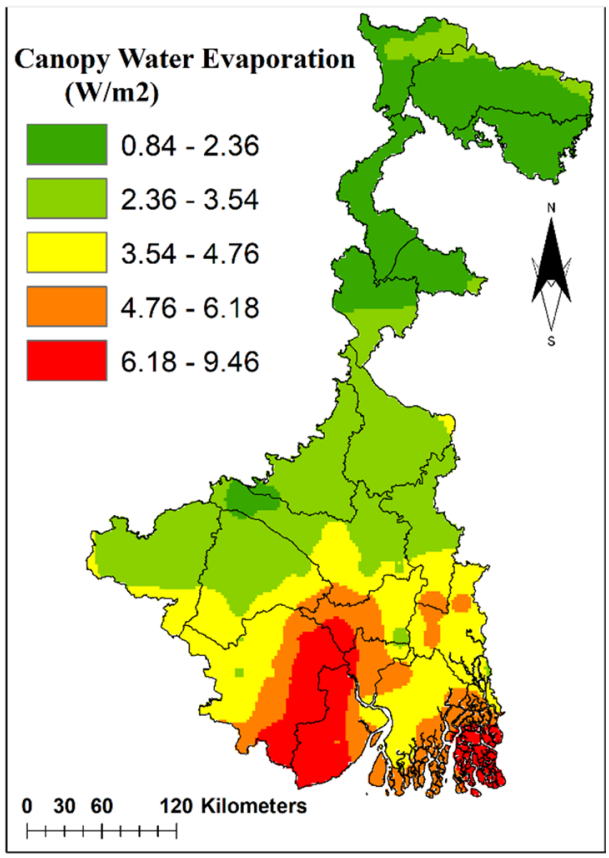

(d) district-wise sustainable groundwater planning and management are required.

Water storage of Indian has decreasing trend over the past few years. Several studies show that the nature and characteristics of depletion using various models and among them, the Gravity Recovery and Climate Experiment (GRACE) observation has significant importance (Bhanja et al. 2020). According to numerous literature regarding GRACE and groundwater, it is obvious that there are very few studies have been conducted on Indian region (Panda and Wahr 2016; Chinnasamy et al. 2013; Long et al. 2016). Therefore, the specific yield wise database is still not available in Indian regions. Thus, fixed specific yield values have been used to estimate the groundwater levels for these regions (Rodell et al. 2009; Panda and Wahr 2016). 
Fig. 11 a DEBS, b PCSW, c PER and $\mathbf{d}$ ST mapping from GLDAS data for pre-monsoon season of 2014

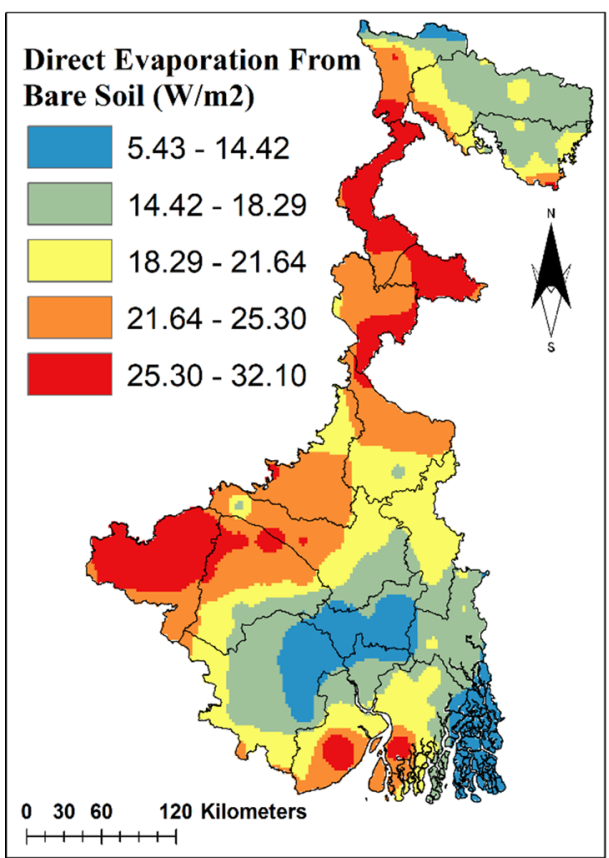

(a)

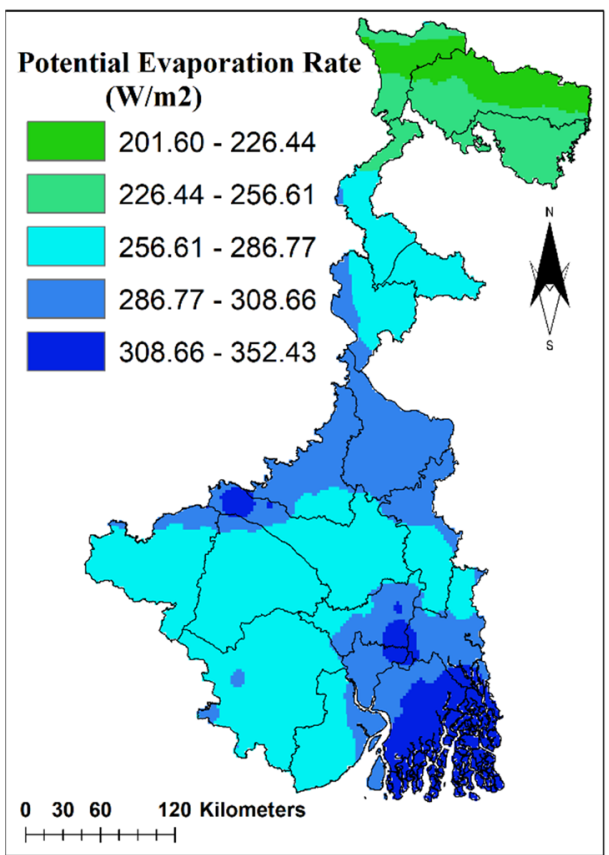

(c) pre-monsoon season of 2014.

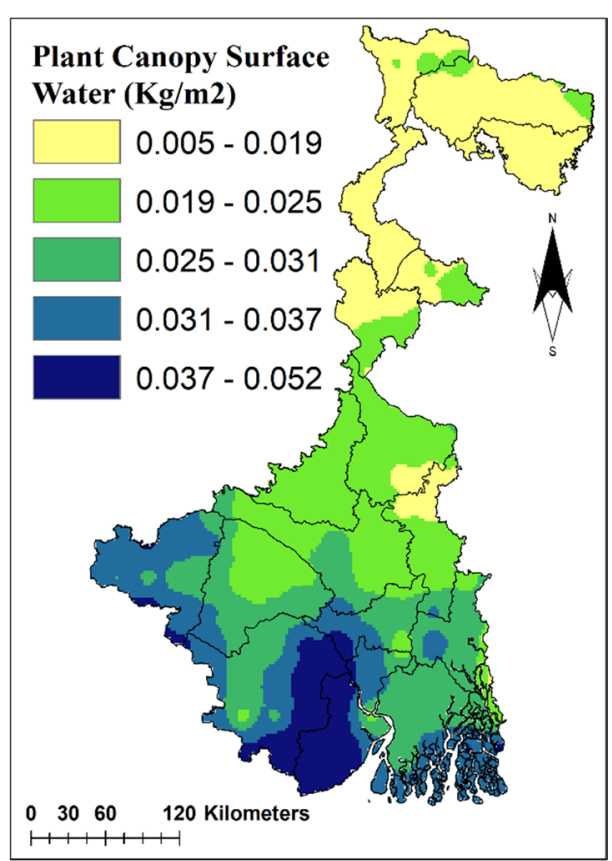

(b)

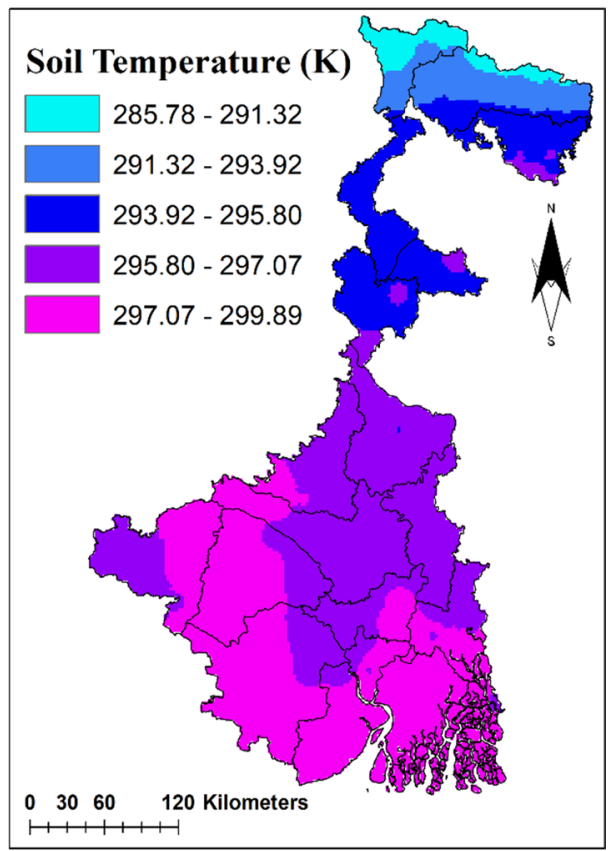

(d)
In India, high exploited groundwater zones are located in Punjab, Haryana, and Delhi regions due to agricultural and population increments which were reported in Central Groundwater Board report 2017-2018. In this connection, the gross extraction of groundwater was increased 62-63\% over the Indian region. In the case of West Bengal, this depletion is caused by dying of wells due to continuous temperature rise and submersible pumping in the agricultural field which creates a vulnerable condition for Bankura, Puruliya, and West Midnapore districts (Halder et al. 2020). A significant transition of land use and land cover over the Bengal regions is also in a changing nature which has a significant impact on the groundwater levels and leads toward its imprints in groundwater scarcity. In this connection, 
Table 1 Assigned and normalized weights of the individual features of the ten feature for groundwater stress zoning

\begin{tabular}{|c|c|c|c|c|c|c|}
\hline SL No & Feature & Weight & Feature classes & Area in $\%$ & $\begin{array}{l}\text { Weight } \\
\text { assigned }\end{array}$ & Normalized weight \\
\hline \multirow[t]{5}{*}{1} & \multirow[t]{5}{*}{ Terrestrial water storage $(\mathrm{mm})$} & \multirow[t]{5}{*}{8} & $682.04-828.16$ & 19.46 & 8 & 0.3333 \\
\hline & & & $828.16-941.82$ & 23.18 & 6 & 0.2500 \\
\hline & & & $941.82-1052.76$ & 33.40 & 5 & 0.2083 \\
\hline & & & $1052.76-1155.59$ & 16.15 & 3 & 0.1250 \\
\hline & & & 1155.59-1372.07 & 7.81 & 2 & 0.0833 \\
\hline \multirow[t]{5}{*}{2} & \multirow[t]{5}{*}{ Groundwater storage (mm) } & \multirow[t]{5}{*}{9} & $503.97-620.71$ & 21.36 & 8 & 0.2759 \\
\hline & & & $620.71-704.09$ & 20.52 & 7 & 0.2414 \\
\hline & & & $704.09-801.77$ & 31.60 & 6 & 0.2069 \\
\hline & & & $801.77-906.59$ & 18.70 & 5 & 0.1724 \\
\hline & & & 906.59-1111.48 & 7.83 & 3 & 0.1034 \\
\hline \multirow[t]{5}{*}{3} & \multirow[t]{5}{*}{ Surface soil moisture $\left(\mathrm{Kg} / \mathrm{m}^{2}\right)$} & \multirow[t]{5}{*}{6} & $2.43-3.70$ & 14.19 & 7 & 0.3889 \\
\hline & & & $3.70-4.18$ & 26.71 & 5 & 0.2778 \\
\hline & & & $4.18-4.65$ & 27.10 & 3 & 0.1667 \\
\hline & & & $4.65-5.16$ & 28.09 & 2 & 0.1111 \\
\hline & & & $5.16-6.57$ & 3.92 & 1 & 0.0556 \\
\hline \multirow[t]{5}{*}{4} & \multirow[t]{5}{*}{ Root zone soil moisture $\left(\mathrm{Kg} / \mathrm{m}^{2}\right)$} & \multirow[t]{5}{*}{6} & 176.29-201.17 & 15.84 & 6 & 0.3529 \\
\hline & & & $201.17-220.71$ & 29.83 & 5 & 0.2941 \\
\hline & & & $220.71-241.44$ & 21.68 & 3 & 0.1765 \\
\hline & & & $241.44-265.73$ & 15.45 & 2 & 0.1176 \\
\hline & & & $265.73-327.33$ & 17.19 & 1 & 0.0588 \\
\hline \multirow[t]{5}{*}{5} & \multirow[t]{5}{*}{ Profile soil moisture $\left(\mathrm{Kg} / \mathrm{m}^{2}\right)$} & \multirow[t]{5}{*}{5} & $682.04-825.46$ & 19.51 & 6 & 0.3529 \\
\hline & & & $825.46-939.11$ & 24.21 & 5 & 0.2941 \\
\hline & & & 939.11-1050.05 & 30.88 & 3 & 0.1765 \\
\hline & & & $1050.05-1155.59$ & 17.23 & 2 & 0.1176 \\
\hline & & & 1155.59-1372.07 & 8.17 & 1 & 0.0588 \\
\hline \multirow[t]{5}{*}{6} & \multirow[t]{5}{*}{ Canopy water evaporation $\left(\mathrm{W} / \mathrm{m}^{2}\right)$} & \multirow[t]{5}{*}{3} & $0.84-2.36$ & 22.80 & 1 & 0.0476 \\
\hline & & & $2.36-3.54$ & 34.41 & 2 & 0.0952 \\
\hline & & & $3.54-4.76$ & 21.94 & 5 & 0.2381 \\
\hline & & & $4.76-6.18$ & 11.49 & 6 & 0.2857 \\
\hline & & & $6.18-9.46$ & 9.35 & 7 & 0.3333 \\
\hline \multirow[t]{5}{*}{7} & \multirow[t]{5}{*}{ Direct evaporation from bare soil $\left(\mathrm{W} / \mathrm{m}^{2}\right)$} & \multirow[t]{5}{*}{3} & $5.43-14.42$ & 10.83 & 2 & 0.0909 \\
\hline & & & $14.42-18.29$ & 26.21 & 3 & 0.1364 \\
\hline & & & $18.29-21.64$ & 23.45 & 4 & 0.1818 \\
\hline & & & $21.64-25.30$ & 24.02 & 6 & 0.2727 \\
\hline & & & $25.30-32.10$ & 15.49 & 7 & 0.3182 \\
\hline \multirow[t]{5}{*}{8} & \multirow[t]{5}{*}{ Potential evaporation rate $\left(\mathrm{W} / \mathrm{m}^{2}\right)$} & 2 & $201.60-226.44$ & 6.09 & 1 & 0.0500 \\
\hline & & & $226.44-256.61$ & 9.99 & 3 & 0.1500 \\
\hline & & & $256.61-286.77$ & 48.65 & 4 & 0.2000 \\
\hline & & & $286.77-308.66$ & 26.08 & 5 & 0.2500 \\
\hline & & & $308.66-352.43$ & 9.19 & 7 & 0.3500 \\
\hline 9 & Plant canopy surface water $\left(\mathrm{Kg} / \mathrm{m}^{2}\right)$ & 4 & $0.005-0.019$ & 23.78 & 7 & 0.2927 \\
\hline & & & $0.019-0.025$ & 28.58 & 6 & 0.2509 \\
\hline & & & $0.025-0.031$ & 22.10 & 5 & 0.2091 \\
\hline & & & $0.031-0.037$ & 17.11 & 4 & 0.1673 \\
\hline & & & $0.037-0.052$ & 8.43 & 2 & 0.0800 \\
\hline
\end{tabular}


Table 1 (continued)

\begin{tabular}{lllllll}
\hline SL No & Feature & Weight & Feature classes & Area in \% & $\begin{array}{l}\text { Weight } \\
\text { assigned }\end{array}$ & Normalized weight \\
\hline 10 & Soil temperature (K) & 2 & $285.78-291.32$ & 3.14 & 2 & 0.0952 \\
& & & $291.32-293.92$ & 6.26 & 3 & 0.1429 \\
& & $293.92-295.80$ & 14.75 & 4 & 5 & 0.1905 \\
& & $295.80-297.07$ & 36.93 & 7 & 0.3333 \\
\hline
\end{tabular}

Table 2 Pair-wise comparison matrix (ten feature layers) developed for AHP based groundwater stress zoning

\begin{tabular}{|c|c|c|c|c|c|c|c|c|c|c|c|}
\hline Feature & TWS & GWS & SSM & RZSM & PSM & CWE & DEBS & PER & PCSW & ST & $\begin{array}{l}\text { Normal- } \\
\text { ized } \\
\text { weights }\end{array}$ \\
\hline TWS & $8 / 8$ & $8 / 9$ & $8 / 6$ & $8 / 6$ & $8 / 5$ & $8 / 3$ & $8 / 3$ & $8 / 2$ & $8 / 4$ & $8 / 2$ & 0.1667 \\
\hline GWS & $9 / 8$ & $9 / 9$ & $9 / 6$ & $9 / 6$ & $9 / 5$ & $9 / 3$ & $9 / 3$ & $9 / 2$ & $9 / 4$ & $9 / 2$ & 0.1875 \\
\hline SSM & $6 / 8$ & $6 / 9$ & $6 / 6$ & $6 / 6$ & $6 / 5$ & $6 / 3$ & $6 / 3$ & $6 / 2$ & $6 / 4$ & $6 / 2$ & 0.1250 \\
\hline RZSM & $6 / 8$ & $6 / 9$ & $6 / 6$ & $6 / 6$ & $6 / 5$ & $6 / 3$ & $6 / 3$ & $6 / 2$ & $6 / 4$ & $6 / 2$ & 0.1250 \\
\hline PSM & $5 / 8$ & $5 / 9$ & $5 / 6$ & $5 / 6$ & $5 / 5$ & $5 / 3$ & $5 / 3$ & $5 / 2$ & $5 / 4$ & $5 / 2$ & 0.1042 \\
\hline CWE & $3 / 8$ & $3 / 9$ & $3 / 6$ & $3 / 6$ & $3 / 5$ & $3 / 3$ & $3 / 3$ & $3 / 2$ & $3 / 4$ & $3 / 2$ & 0.0625 \\
\hline DEBS & $3 / 8$ & $3 / 9$ & $3 / 6$ & $3 / 6$ & $3 / 5$ & $3 / 3$ & $3 / 3$ & $3 / 2$ & $3 / 4$ & $3 / 2$ & 0.0625 \\
\hline PER & $2 / 8$ & $2 / 9$ & $2 / 6$ & $2 / 6$ & $2 / 5$ & $2 / 3$ & $2 / 3$ & $2 / 2$ & $2 / 4$ & $2 / 2$ & 0.0417 \\
\hline PCSW & $4 / 8$ & $4 / 9$ & $4 / 6$ & $4 / 6$ & $4 / 5$ & $4 / 3$ & $4 / 3$ & $4 / 2$ & $4 / 4$ & $4 / 2$ & 0.0833 \\
\hline ST & $2 / 8$ & $2 / 9$ & $2 / 6$ & $2 / 6$ & $2 / 5$ & $2 / 3$ & $2 / 3$ & $2 / 2$ & $2 / 4$ & $2 / 2$ & 0.0417 \\
\hline
\end{tabular}

TWS terrestrial water storage, GWS groundwater storage, SSM surface soil moisture, RZSM root zone soil moisture, $P S M$ profile soil moisture, $C W E$ canopy water evaporation, $D E B S$ direct evaporation from bare soil, $P E R$ potential evaporation rate, $P C S W$ plant canopy surface water, $S T$ soil temperature

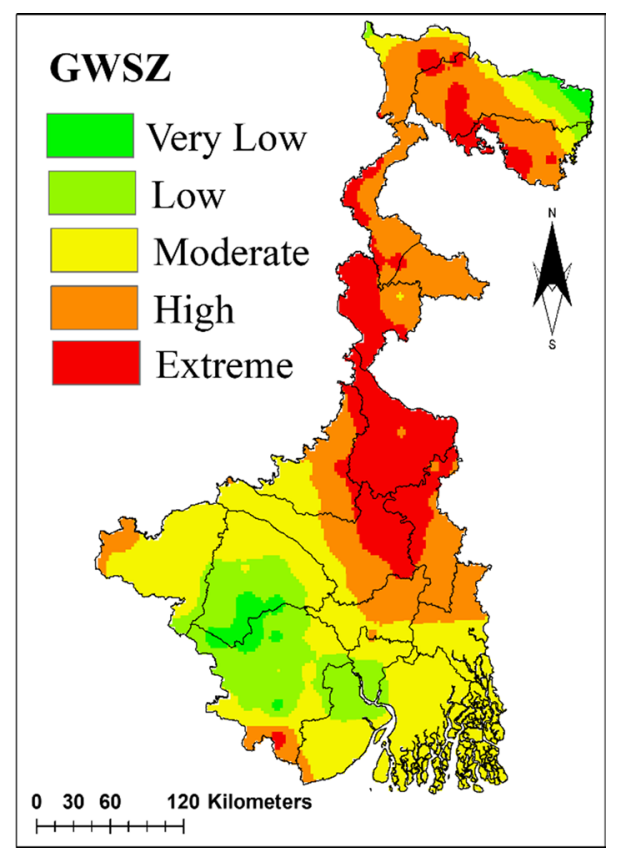

Fig. 12 Delineation of groundwater stress zone (GWSZ) mapping using AHP method for pre-monsoon season of 2014 the poor recharge trends in the south-west monsoon along with very slow recharge trends in post-monsoon have been notices due to poor precipitation consistency and infiltration rates. Simultaneously, the changes in the pattern of rainfall intensity in certain periods also create a negative impact on groundwater recharge. High precipitation in a shorter time duration, on one hand increase the potential for flooding, and also secure water supply (Salimi et al. 2019), on the other hand, with the erosion of topsoil creates a negative ambiance for natural groundwater recharge over the Bengal region over the last few decades which are one of the key factors of groundwater scarcity.

Few numbers of researchers worked on the identification of groundwater potential zones in West Bengal. Ghosh et al. (2016) studied groundwater potential zone in the hard rock terrain of Kumari watershed in the western part of West Bengal. It is observed that very low crop cultivation in this watershed covered by Purulia district because of this region under high water stress. Thus, excessive groundwater used for irrigation, domestic and various purposes (Mandal et al. 2016). Identification of groundwater recharge potential zone based on AHP method in the critical Goghat-II 
Table 3 Area under different classes change with exclusion of each groundwater stress parameter

\begin{tabular}{lllllll}
\hline$i$ & Feature & \multicolumn{3}{l}{ \% Change } & & \\
\cline { 3 - 7 } & & Very low & Low & Moderate & High & Extreme \\
\hline 1 & TWS & +0.12 & -0.92 & $\mathbf{+ 2 . 2 7}$ & $\mathbf{+ 3 . 4 9}$ & $\mathbf{- 4 . 9 6}$ \\
2 & GWS & $\mathbf{- 2 . 7 7}$ & $\mathbf{- 1 0 . 4 2}$ & $\mathbf{+ 1 0 . 6 9}$ & -0.03 & $\mathbf{+ 2 . 5 4}$ \\
3 & SSM & +0.09 & +0.64 & +0.26 & $\mathbf{+ 2 . 4 2}$ & $\mathbf{- 3 . 4 1}$ \\
5 & RZSM & +0.16 & +0.25 & +0.91 & $\mathbf{+ 3 . 4 8}$ & $\mathbf{- 4 . 8 0}$ \\
5 & PSM & +0.12 & -0.92 & $+\mathbf{2 . 2 7}$ & $\mathbf{+ 3 . 4 9}$ & $\mathbf{- 4 . 9 6}$ \\
6 & CWE & +0.16 & +0.79 & +0.20 & +1.98 & $\mathbf{- 3 . 1 3}$ \\
7 & DEBS & +0.06 & +0.54 & +0.71 & $\mathbf{+ 2 . 8 3}$ & $\mathbf{- 4 . 1 3}$ \\
8 & PER & -0.09 & +0.50 & -0.57 & $\mathbf{- 1 . 1 5}$ & $\mathbf{+ 1 . 3 0}$ \\
9 & PCSW & +0.11 & +0.66 & +0.37 & $\mathbf{+ 2 . 1 0}$ & $\mathbf{- 3 . 2 4}$ \\
10 & ST & -0.01 & +0.34 & +0.85 & $\mathbf{+ 2 . 0 5}$ & $\mathbf{- 3 . 2 3}$ \\
$\boldsymbol{S}_{\boldsymbol{F}}$ & All feature & 8.26 & 17.72 & 30.03 & 22.42 & 21.58 \\
\hline
\end{tabular}

Bold values indicate significant results
Table 4 Correlation between five most sensitive parameters for the generation of groundwater stress zone (GWSZ) using Kendall, Pearson and Spearman methods

\begin{tabular}{llllll}
\hline & TWS $_{\mathrm{t}-1}$ & GWS $_{\mathrm{t}-1}$ & RZSM $_{\mathrm{t}-1}$ & PSM $_{\mathrm{t}-1}$ & DEBS $_{\mathrm{t}-1}$ \\
\hline Kendall & & & & & \\
TWS $_{\mathrm{t}-1}$ & 1 & 1 & 0.6000 & 0.8000 & -0.2000 \\
GWS $_{\mathrm{t}-1}$ & 1 & 1 & 0.6000 & 0.8000 & -0.2000 \\
RZSM $_{\mathrm{t}-1}$ & 0.6000 & 0.6000 & 1 & 0.4000 & -0.6000 \\
PSM $_{\mathrm{t}-1}$ & 0.8000 & 0.8000 & 0.4000 & 1 & 0 \\
DEBS $_{\mathrm{t}-1}$ & -0.2000 & -0.2000 & -0.6000 & 0 & 1 \\
Pearson & & & & & \\
TWS $_{\mathrm{t}-1}$ & 1 & 1 & 0.7000 & 0.9000 & -0.3000 \\
GWS $_{\mathrm{t}-1}$ & 1 & 1 & 0.7000 & 0.9000 & -0.3000 \\
RZSM $_{\mathrm{t}-1}$ & 0.7000 & 0.7000 & 1 & 0.6000 & -0.7000 \\
PSM $_{\mathrm{t}-1}$ & 0.9000 & 0.9000 & 0.6000 & 1 & -0.1000 \\
DEBS $_{\mathrm{t}-1}$ & -0.3000 & -0.3000 & -0.7000 & -0.1000 & 1 \\
Spearman & & & & & \\
TWS $_{\mathrm{t}-1}$ & 1 & 1 & 0.7000 & 0.9000 & -0.3000 \\
GWS $_{\mathrm{t}-1}$ & 1 & 1 & 0.7000 & 0.9000 & -0.3000 \\
RZSM $_{\mathrm{t}-1}$ & 0.7000 & 0.7000 & 1 & 0.6000 & -0.7000 \\
PSM $_{\mathrm{t}-1}$ & 0.9000 & 0.9000 & 0.6000 & 1 & -0.1000 \\
DEBS $_{\mathrm{t}-1}$ & -0.3000 & -0.3000 & -0.7000 & -0.1000 & 1 \\
\hline
\end{tabular}

$T W S_{t-1}$ terrestrial water storage at time, $G W S_{t-1}$ groundwater storage at time, $R Z S M_{t-1}$ root zone soil moisture at time, $P S M_{t-1}$ profile soil moisture at time, $D E B S_{t-1}$ evaporation from bare soil at time

block, Hooghly is available in Das et al. (2019). The results show that moderate groundwater recharge $(33.51 \%)$ is presented in this block because of the low lying flat plain of the northeastern portion. Patra et al. (2018) also studied AHP-based groundwater potential zone delineation in the whole district of Hooghly for sustainable development. The results show that Arambag, Chinsurah-Mogra, Goghat-I, Pandua, and Polba-Dadpur comes under the semi-critical groundwater development category. John et al. (2018) studied the groundwater level is falling in many parts of the state because of the maximum areas cover by the agricultural land. It is observed that the groundwater declining trend shows in the arsenic prone areas. Sahoo et al. (2019) delineated future groundwater potential zone based on AHP method in the Dwarakeswar-Gandherswari river basin covered by Bankura and Purulia district. The future groundwater results show that the Bankura district comes under poor groundwater potential because of more use of groundwater for irrigation purposes. Marwah (2018) studied arsenic contamination is not serious problems to agriculture in West Bengal but threats to drinking water purposes. However, groundwater contamination is highly increased by arsenic and heavy metal in the twenty administrative districts of Assam (Nath et al. 2018). Thus, the analysis of groundwater contamination is very significant for potable groundwater reserves. Our results agreed with previous publications for district-wise spatiotemporal groundwater storage change from 2000 to 2014 .

\section{Significance of the research work for policy and practice}

This study is a pioneering step in applying data science technologies to developing a sustainable water management framework. In this research, terrestrial water storage (TWS) and groundwater storage (GWS) scenarios will be used for solving the problem of water for agriculture and domestic purpose under climate uncertainty. This approach is effective as it considers future climate data of agricultural activities for the development of innovative technologies and management systems. Future climate data can strengthen their capacity for adaptation to climate based upon the farmer's attitude toward risk. 


\section{Recommendation for sustainable groundwater management}

The groundwater is valuable natural resources for the present and future agriculture, cities, health, and environment. It provides a dependable and long-term water supply for current and future generations and also provides additional water for drought when there is not enough snow or rainfall (Menon 2007; California Water Foundation 2014). The following recommendations should be advanced in order to ensure groundwater sustainable for India, particularly for West Bengal:

- Adopting an actual definition of sustainable groundwater management.

- Established local groundwater management authorities.

- Established a system of prioritization for all sub-basins.

- Properly utilized of surface water for agriculture cultivation.

- Eco-efficient agriculture planning is required for sustainable agriculture management.

- Interconnection between groundwater and surface water.

- Improve groundwater data availability through an opensource web service portal.

- Increasing groundwater storage for highly variable water supplies due to climate uncertainty.

- Full control over the exploitation of the study area's natural resources is necessary to promote socioeconomic development.

- Providing financial support for groundwater management.

\section{Conclusions}

The groundwater is very relevant for the effect of future climate change on groundwater resources worldwide. In the present research, district-wise spatiotemporal GWS changes have been performed under TWS using GLDAS2 CLSM data for pre-monsoon season to correlated with observed groundwater level and recharge values. The research objective mainly focuses on the delineation of the groundwater stress zone based on ten biophysical and hydrological parameters [i.e. terrestrial water storage (TWS), groundwater storage (GWS), surface soil moisture (SSM), root zone soil moisture (RZSM), profile soil moisture (PSM), canopy water evaporation (CWE), direct evaporation from bare soil (DEBS), potential evaporation rate (PER), plant canopy surface water (PCSW), and soil temperature (ST)] using AHP method by the
GIS environment. During current work, the district-wise spatiotemporal pre-monsoon soil moisture change were analyzed to identify the water stress areas. Pre-monsoon season is only considered because of the water stress problem shown in this season. Population data also considered for the identification of groundwater stress zones. The results indicated that moderate water stress zones are shown in the district of Birbhum, Bankura, Purulia (max: $3.82 \mathrm{~kg} / \mathrm{m}^{2)}$ according to surface soil moisture condition. The results showed that the districts Jalpaiguri (max: $1097.35 \mathrm{~mm}$ ), Paschim Medinipore ( $\max : 993.22 \mathrm{~mm}$ ), Purba Medinipore (max: $903.43 \mathrm{~mm}$ ) and a small part of the Bankura (max: $932.69 \mathrm{~mm}$ ) had high groundwater storage. The TWS components like soil moisture, surface waters, snow, glaciers, and biomass did not significantly contribute to the decline of the total water level. It can be a cause of unstainable groundwater for irrigation and other anthropogenic activities. The results also indicated that the groundwater stress zone in the district of North 24 Parganas (max: $755.12 \mathrm{~mm}$ ) due to the highest population pressure compared to the other districts. The sensitivity analysis has been performed to identify the most significant high impact parameters on groundwater stress zones (GWSZ). However, the total urban and rural population in West Bengal is 57,748,946 and 22,427,251 under $80,176,197$ total populations from 2001 due to the degree of urbanization. These population values proved that the increased urban population for this state. The decennial growth rate is increased from 1991 to 2001 compared to 2001 to 2011. Thus, groundwater is more utilized for drinking and agriculture purposes. Proper scientific and systematic planning is required for district-wise sustainable groundwater management shortly. The major drawback of present study is the lack of groundwater data. Several groundwater data can be utilized for the more accuracy of the district-wise groundwater output. This research output can be utilized for regional future sustainable groundwater planning and management.

Acknowledgments The author thanks Irrigation and Waterways Directorate, Government of West Bengal, India for providing necessary support for this research work. The author also thanks Regional Director, Central Ground Water Board (CGWB) for providing necessary data for this research work.

\section{Compliance with ethical standards}

Conflicts of interest The authors declare that they have no conflict of interest. 


\section{References}

Anderson MP, Woessner WW, Hunt RJ (2015) Applied groundwater modeling: simulation of flow and advective transport. Academic Press, San Diego

Bandyopadhyay S, Kar NS, Das S, Sen J (2014) River systems and water resources of West Bengal: a review. Geol Soc India Spec Publ 3(2014):63-84

Bhanja SN, Mukherjee A, Rodell M (2020) Groundwater storage change detection from in situ and GRACE-based estimates in major river basins across India. Hydrol Sci J 65(4):650-659

Chatterjee RS, Pranjal P, Jally S, Kumar B, Dadhwal VK, Srivastav SK, Kumar D (2020) Potential groundwater recharge in north-western India vs spaceborne GRACE gravity anomaly based monsoonal groundwater storage change for evaluation of groundwater potential and sustainability. Groundw Sustain Dev 10:100307

Castle SL, Thomas BF, Reager JT, Rodell M, Swenson SC, Famiglietti JS (2014) Groundwater depletion during drought threatens future water security of the Colorado River Basin. Geophys Res Lett 41:5904-5911

California Water Foundation (2014) Recommendation for sustainable groundwater management: developed through a stakeholder dialogue, pp 1-40

Chinnasamy P, Hubbart JA, Agoramoorthy G (2013) Using remote sensing data to improve groundwater supply estimations in Gujarat, India. Earth Interact 17(1):1-17

Chinnasamy P, Maheshwari B, Dillon P, Purohit R, Dashora Y, Soni P, Dashora R (2018) Estimation of specific yield using water table fluctuations and cropped area in a hardrock aquifer system of Rajasthan, India. Agric Water Manag 202:146-155

da Costa AM, de Salis HHC, Viana JHM, Leal Pacheco FA (2019) Groundwater recharge potential for sustainable water use in urban areas of the Jequitiba River Basin. Brazil Sustain 11:2955

Das B, Pal SC (2019a) Assessment of groundwater recharge and its potential zone identification in groundwater-stressed Goghat-I block of Hugli District, West Bengal, India. Environ Dev Sustain 22:5905-5923

Das B, Pal SC (2019b) Combination of GIS and fuzzy-AHP for delineating groundwater recharge potential zones in the critical Goghat-II block of West Bengal, India. Hydro Res 2(1):21-30

Das B, Pal SC, Malik S, Chakrabortty R (2019) Modeling groundwater potential zones of Puruliya district, West Bengal, India using remote sensing and GIS techniques. Geol, Ecol, Landsc 3(3):223-237

Dasgupta S, Das IC, Subramanian SK, Dadhwal VK (2014) Spacebased gravity data analysis for groundwater storage estimation in the Gangetic plain, India. Curr Sci 107(5):832-844

Dhar A, Sahoo S, Sahoo M (2015) Identification of groundwater potential zones considering water quality aspect. Environ Earth Sci 74:5663-5675

De Ridder K (2001) Rainwater storage on plant canopies. J Geophys Res: Atmos 106(D14):14819-14825

Dhar A, Sahoo S, Dey S, Sahoo M (2014) Evaluation of recharge and groundwater dynamics of a shallow alluvial aquifer in central Ganga basin, Kanpur (India). Nat Resour Res 23(4):409-422

Döll P, Fiedler K (2009) Global-scale modeling of groundwater recharge. Hydrol Earth Syst Sci 12:863-885

Döll P, Kaspar F, Lehner B (2003) A global hydrological model for deriving water availability indicators: model tuning and validation. J Hydrol 270(1-2):105-134

Frappart F, Papa F, Güntner A, Tomasella J, Pfeffer J, Ramillien G, Moreira D (2019) The spatio-temporal variability of groundwater storage in the Amazon River Basin. Adv Water Resour 124:41-52
Famiglietti JS, Lo M, Ho SL, Bethune J, Anderson KJ, Syed TH, Swenson SC, De Linage CR, Rodell M (2011) Satellites measure recent rates of groundwater depletion in California's Central Valley. Geophys Res Lett 38:L03403

Ghosh PK, Bandyopadhyay S, Jana NC (2016) Mapping of groundwater potential zones in hard rock terrain using geoinformatics: a case of Kumari watershed in western part of West Bengal. Model Earth Syst Environ 2(1): 1

Gleeson T, Wada Y (2013) Assessing regional groundwater stress for nations using multiple data sources with the groundwater footprint. Environ Res Lett 8:044010

Girotto M, Rodell M (2019) Terrestrial water storage. In: Extreme hydroclimatic events and multivariate hazards in a changing environment: a remote sensing approach, 1st edn. Elsevier, pp 41-64

Halder S, Roy MB, Roy PK (2020) Analysis of groundwater level trend and groundwater drought using standard groundwater level index: a case study of an eastern river basin of West Bengal. India SN Appl Sci 2(3):1-24

Han D, Cao G (2018) Phase difference between groundwater storage changes and groundwater level fluctuations due to compaction of an aquifer-aquitard system. J Hydrol 566:89-98

Herbert C, Döll P (2019) Global assessment of current and future groundwater stress with a focus on transboundary aquifers. Water Resour Res 55(6):4760-4784

Herrera-Pantoja M, Hiscock K (2008) The effects of climate change on potential groundwater recharge in Great Britain. Hydrol Process 22:73-86

Holman I, Tascone D, Hess TA (2009) Comparison of stochastic and deterministic downscaling methods for modelling potential groundwater recharge under climate change in East Anglia, UK: implications for groundwater resource management. Hydrogeol J 17:1629-1641

Islam MSN, Gnauck A (2009) Threats to the Sundarbans mangrove wetland ecosystems from transboundary water allocation in the Ganges basin: A preliminary problem analysis. Int J Ecol Econ Stat 13(9):64-78

Jakeman AJ, Barreteau O, Hunt RJ, Rinaudo JD, Ross A (2017) Integrated groundwater management concepts, approaches and challenges, 54th edn. Springer, Berlin

John B, Das R, Das S (2018) An overview of the development of groundwater resources in India with special reference to West Bengal and Kolkata. Int J Emerg Trends Eng Dev 8(3):1-10

Jyrkama MI, Sykes JF (2007) The impact of climate change on spatially varying groundwater recharge in the grand river watershed (Ontario). J Hydrol 338:237-250

Kundewicz ZW, Döll P (2009) Will groundwater ease freshwater stress under climate change? Hydrol Sci J 54:665-675

Liu L, Parkinson S, Gidden M, Byers E, Sato Y, Riahi K, Forman B (2018) Quantifying the potential for reservoirs to secure future surface water yields in the world's largest river basins. Environ Res Lett 13(4):044026

Li X, Xu X, Liu W, Xu C, Zhang R, Wang K (2019) Prediction of profile soil moisture for one land use using measurements at a soil depth of other land uses in a karst depression. J Soils Sediments 19(3):1479-1489

Long D, Chen X, Scanlon BR, Wada Y, Hong Y, Singh VP, Yang W (2016) Have GRACE satellites overestimated groundwater depletion in the Northwest India Aquifer? Sci Rep 6:24398

Mandal U, Sahoo S, Munusamy SB, Dhar A, Panda SN, Kar A, Mishra PK (2016) Delineation of groundwater potential zones of coastal groundwater basin using multi-criteria decision making technique. Water Resour Manage 30(12):4293-4310

Menon SV (2007) Ground water management: need for sustainable approach. MPRA Paper No. 6078, posted 4 December 
Mohan C, Western AW, Wei Y, Saft M (2018) Predicting groundwater recharge for varying land cover and climate conditions-a global meta-study. Hydrol Earth Syst Sci 22:2689-2703

Marwah M (2018) Mapping institutions for assessing groundwater scenario in West Bengal, India. Institute for Social and Economic Change, Bangalore

Mukherjee A, Bhanja SN, Wada Y (2018) Groundwater depletion causing reduction of baseflow triggering Ganges river summer drying. Sci Rep 8(1):1-9

Nath BK, Chaliha C, Bhuyan B, Kalita E, Baruah DC, Bhagabati AK (2018) GIS mapping-based impact assessment of groundwater contamination by arsenic and other heavy metal contaminants in the Brahmaputra River valley: a water quality assessment study. J Clean Prod 201:1001-1011

Panda DK, Wahr J (2016) Spatiotemporal evolution of water storage changes in India from the updated GRACE-derived gravity records. Water Resour Res 52(1):135-149

Patra S, Mishra P, Mahapatra SC (2018) Delineation of groundwater potential zone for sustainable development: a case study from Ganga Alluvial Plain covering Hooghly district of India using remote sensing, geographic information system, and analytic hierarchy process. J Clean Prod 172:2485-2502

Piantanakulchai M, Saengkhao N (2003) Evaluation of alternatives in transportation planning using multi-stakeholders multi-objectives AHP modeling. Proc Eastern Asia Soc Trans Stud 4:1613-1628

Richey AS, Thomas BF, Lo MH, Reager JT, Famiglietti JS, Voss K, Rodell M (2015) Quantifying renewable groundwater stress with GRACE. Water Resour Res 51(7):5217-5238

Rodell M, Houser PR, Jambor U, Gottschalck J, Mitchell K, Meng CJ, Arsenault K, Cosgrove B, Radakovich J, Bosilovich M, Entin JK, Walker JP, Lohmann D, Toll D (2004) The global land data assimilation system. Bull Am Meteor Soc 85:381-394

Rodell M, Velicogna I, Famiglietti JS (2009) Satellite-based estimates of groundwater depletion in India. Nature 460:999-1002

Saaty TL (1980) The analytic hierarchy process: planning, priority setting, resource allocation. McGraw Hill, New York

Saaty TL (1990) Multicriteria decision making: the analytic hierarchy process: planning, priority setting. Resour Alloc 2:1-20

Sahoo S, Dhar A, Debsarkar A, Kar A (2019) Future scenarios of environmental vulnerability mapping using grey analytic hierarchy process. Nat Resour Res 28(4):1461-1483

Salimi AH, Masoompour Samakosh J, Sharifi E, Hassanvand MR, Noori A, von Rautenkranz H (2019) Optimized artificial neural networks-based methods for statistical downscaling of gridded precipitation data. Water 11(8):1653

Shamsudduha M, Taylor RG, Longuevergne L (2012) Monitoring groundwater storage changes in the highly seasonal humid tropics: validation of GRACE measurements in the Bengal Basin. Water Resour Res 48(2):1-12

Shankar PV, Kulkarni H, Krishnan S (2011) India's groundwater challenge and the way forward. Econ Political Weekly 46(2):37-45

Shah T (2009) Taming the anarchy: groundwater governance in South Asia. Resources for the future, Washington and International Water Management Institute, Colombo

Sharifi E, Eitzinger J, Dorigo W (2019) Performance of the state-ofthe-art gridded precipitation products over mountainous terrain: a regional study over Austria. Remote Sens 11(17):1-20

Singh AK, Jasrotia AS, Taloor AK, Kotlia BS, Kumar V, Roy S, Sharma AK (2017) Estimation of quantitative measures of total water storage variation from GRACE and GLDAS-NOAH satellites using geospatial technology. Quat Int 444:191-200

Singh R, Kumar R (2019) Climate versus demographic controls on water availability across India at $1.5^{\circ} \mathrm{C}, 2.0^{\circ} \mathrm{C}$ and $3.0^{\circ} \mathrm{C}$ global warming levels. Global Planet Change 177:1-9

Singh DK, Singh AK (2002) Groundwater situation in India: problems and perspectives. Int J Water Resour Dev 18(4):563-580

Singh AK, Tripathi JN, Kotlia BS, Singh KK, Kumar A (2019) Monitoring groundwater fluctuations over India during Indian Summer Monsoon (ISM) and Northeast monsoon using GRACE satellite: Impact on agriculture. Quatern Int 507:342-351

Sridhar V, Ali SA, Lakshmi V (2019) Assessment and validation of total water storage in the Chesapeake Bay watershed using GRACE. J Hydrol: Reg Stud 24:100607

Torres-Rua A, Ticlavilca A, Bachour R, McKee M (2016) Estimation of surface soil moisture in irrigated lands by assimilation of Landsat vegetation indices, surface energy balance products, and relevance vector machines. Water 8(4): 167

Vaux H (2011) Groundwater under stress: the importance of management. Environ Earth Sci 62:19-23

Voss KA, Famiglietti JS, Lo M, De Linage C, Rodell M, Swenson SC (2013) Groundwater depletion in the Middle East from GRACE with implications for transboundary water management in the Tigris-Euphrates-Western Iran region. Water Resour Res 49:904-914

Wakode HB, Baier K, Jha R, Azzam R (2018) Impact of urbanization on groundwater recharge and urban water balance for the city of Hyderabad, India. Int Soil Water Conserv Res 6(1):51-62

Youssef AM (2015) Landslide susceptibility delineation in the ArRayth area, Jizan, Kingdom of Saudi Arabia, using analytical hierarchy process, frequency ratio, and logistic regression models. Environ Earth Sci 73(12):8499-8518

\section{Affiliations}

\section{Satiprasad Sahoo ${ }^{1}$ Subha Chakraborty ${ }^{2}$ Quoc Bao Pham ${ }^{3,4}$. Ehsan Sharifi ${ }^{5}$ Saad Sh. Sammen ${ }^{6}$ Matej Vojtek $^{7}$. Jana Vojteková $\cdot$ Ismail Elkhrachy ${ }^{8,9} \cdot$ Romulus Costache $^{10,11} \cdot$ Nguyen Thi Thuy Linh ${ }^{12,13}$}

1 Centre for Environment, Indian Institute of Technology Guwahati, Guwahati 781039, India

2 Department of Architecture, Town and Regional Planning, IIEST, Shibpur, Howrah 711 103, India

3 Environmental Quality, Atmospheric Science and Climate Change Research Group, Ton Duc Thang University, Ho Chi Minh City, Vietnam

4 Faculty of Environment and Labour Safety, Ton Duc Thang University, Ho Chi Minh City, Vietnam
5 Section 4.4 Hydrology, GFZ German Research Centre for Geosciences, 14473 Potsdam, Germany

6 Department of Civil Engineering, College of Engineering, University of Diyala, Baqubah, Diyala Governorate, Iraq

7 Department of Geography and Regional Development, Faculty of Natural Sciences, Constantine the Philosopher University in Nitra, Trieda A. Hlinku 1, 94901 Nitra, Slovakia 
8 Najran University, College of Engineering, Civil Engineering Department, King Abdulaziz Road, P.O Box 1988, Najran, Saudi Arabia

9 Al-Azhar University, Faculty of Engineering, Civil Engineering Department, Nasr City, Cairo 11371, Egypt

10 Research Institute of the University of Bucharest, 90-92 Sos. Panduri, 5th District, 050663 Bucharest, Romania
11 National Institute of Hydrology and Water Management, București-Ploiești Road, 97E, 1st District, 013686 Bucharest, Romania

12 Institute of Research and Development, Duy Tan University, Danang 550000, Vietnam

13 Faculty of Environmental and Chemical Engineering, Duy Tan University, Danang 550000, Vietnam 